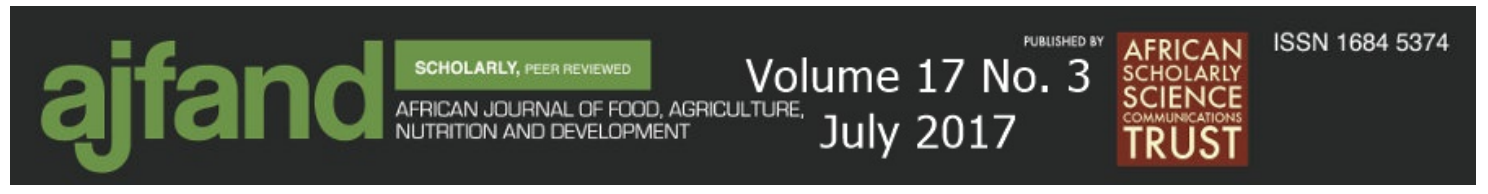

Afr. J. Food Agric. Nutr. Dev. 2017; 17(3): 12256-12279

DOI: 10.18697/ajfand.79.15855

\title{
QUALITY CHARACTERISTICS AND ACCEPTABILITY OF LOW COST WEANING BLENDS BY ZAMBIAN MOTHERS
}

Hayes $\mathrm{RE}^{1^{*}}$, Zulu $\mathrm{RM}^{2}$, Mulenga $\mathrm{DK}^{3}$ and MT Kaputo ${ }^{4}$

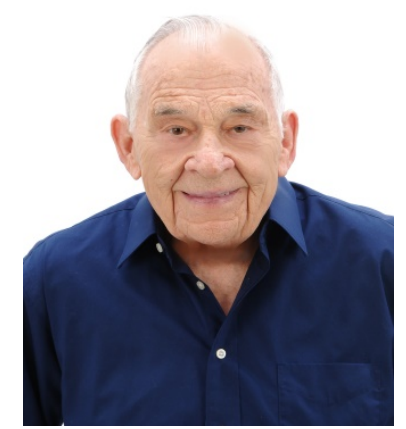

Robert E Hayes

*Corresponding author e-mail: ralhayes@,bellsouth.net

${ }^{1}$ U.S. Department of Agriculture, Southern Regional Research Center, 1100 Robert E. Lee Blvd. New Orleans, LA, USA 70124-4305

${ }^{2}$ CIAT: International Center for Tropical Agriculture, Chitedze Agriculture Research Station, P.O. Box 158, Lilongwe, Malawi

${ }^{3}$ Lusaka Apex Medical University, P.O. Box 31909, Lusaka, Zambia

${ }^{4}$ Deceased ${ }^{1,2,3,4}$ At the time of the field study, all authors were affiliated with The National Council for Scientific Research, Food Technology Research Unit, International Airport Road, P.O. Box 310158, Chelston 15302, Lusaka, Zambia 


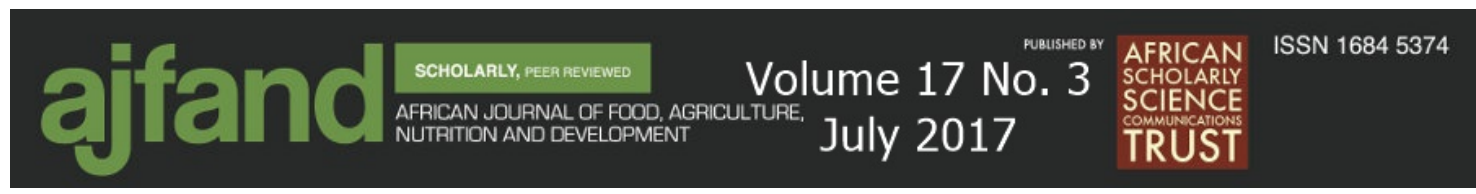

\section{ABSTRACT}

Stunting, and to a lesser extent wasting and undernutrition, of children under five years constitutes a serious health problem in Zambia. Although non-nutritional causes such as infection and poverty importantly exacerbate these conditions, improvements in the diets of children is vital for better health. The age interval beginning at about six months is an especially vulnerable time for children, when they are being weaned from breast milk to conventionally used cultural foods. The current study reports assessments by mothers of nine experimental weaning mixtures, formulated by computer to be low cost and nutritionally superior to maize meal alone. An incomplete block design with randomization was used to compare the nine weaning food blends, differentially constituted to address specific conditions. One group of 127 mothers (or guardians) of children 6 to 27 months judged cooked porridges prepared from the blends. The alternate group of 140 mothers of children from 5 to 30 months evaluated characteristics of uncooked porridge ingredients. Statistical analyses of hedonic scale ratings and tabulation of mothers' voluntary comments were performed. With few exceptions, blend macronutrient/energy characteristics generally conformed to proposed standards in Codex Alimentarius and other literature guidelines. Mixture levels of 20 vitamins and minerals were estimated. A rice-containing formula was most expensive and a high maize/moderate soy formulation the least costly in price assessment. Acceptability results showed that in addition to maize meal and nonfat dry milk, the most acceptable mixtures contained bambara nuts or soybeans as chief ingredients. Blends with substantial percentages of millet, sorghum, or kapenta were not ordinarily acceptable. It was observed that all four cooked porridge quality factors were significantly $(\mathrm{p} \leq 0.01)$ related with each other, and that both ingredient set rating categories were likewise significantly $(p \leq 0,01)$ related. It is emphasized that nutrient contributions of the weaning mixtures are meant for further complementation by concurrent feeding of breast milk, by appropriate use of micronutrient powders or lipidbased micronutrient spreads, and by market or home produced foods. Acceptability results of this study may be influenced by factors such as commodity cost variations, food donations, mother education, and processing cooperatives.

Key words: Weaning foods, nutrition, ingredients, porridges, quality, mothers, acceptability, Zambia 


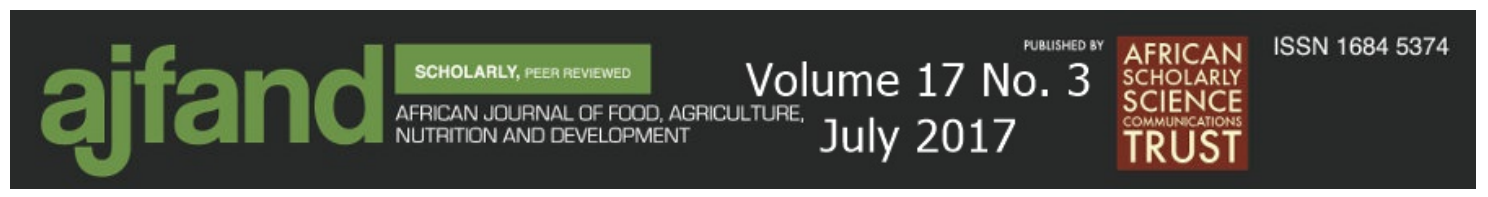

\section{INTRODUCTION}

Stunting is a major health problem in developing countries, and to a lesser frequency, wasting and underweight, among children less than 5 years of age [1]. Based on height-for-age in Zambia, $40 \%$ of children under 5 years have been reported as being moderately stunted and $17 \%$ as severely stunted, having $\mathrm{z}$ scores $<-2$ and $<-3$, respectively [2]. These children are considered to be chronically malnourished, having received inadequate nutrition over an extended period of time. Six percent of Zambian children have been classified as wasted, having a weight-for-height index of $<-2 \mathrm{z}$ score; $2 \%$ with a $<-3 \mathrm{z}$ score are categorized as being severely wasted. These children are designated as acutely malnourished, with failure of adequate nourishment in the interval just preceding the time of status evaluation. Children with a weight-for-age index $<-2 \mathrm{z}$ score, reflecting both stunting and wasting, are classified as underweight; those with an index of $<-3 \mathrm{z}$ score as severely underweight. The prevalence of such children in Zambia has been reported as $15 \%$ and $3 \%$, respectively $[2,3]$.

The diversity and quantity of dietary nutrients are not the only conditions which determine the nutritional status of children. Infection brought upon by poor environmental sanitation and unhygienic practices, inadequate health services, food and nutritional insecurity, and poverty are some other major contributions [4, 5]. Multiple adverse health consequences, studied particularly as a result of childhood stunting, are observed in school-age children, adolescents, and adults throughout life, and are associated with increased morbidity and mortality.

The current study reports an acceptability evaluation of low cost experimental weaning mixtures (Table 1) by Zambian mothers. Porridges of these mixtures were designed to be nutritionally superior to the conventional maize meal porridge they are intended to replace [3]. Feeding of the formulated porridges is to be initiated at 6 months, following exclusive breastfeeding, and is to continue with an increasing gruel viscosity, and thus nutrient density, until the children are about 2 years of age. Souganidis has pointed out that although growth faltering can occur earlier in a baby's development, stunting most often emerges at about 6 months of age as the child makes the transition from breast milk to complementary foods of poor quality or inadequate quantity [1]. The nutrient contributions of the weaning mixtures evaluated in this study are intended to be further complemented by concurrent feeding of breast milk, by appropriate use of micronutrient powders or lipid-based micronutrient spreads, and by market or homeproduced foods $[3,6]$.

Type II nutrients are primarily responsible for growth and type I nutrients for certain biochemical body functions [6]. Michaelsen et al. have listed important characteristics of diets applicable for children with moderate malnutrition [7]. These include: high content of micronutrients, especially growth (type II) nutrients, high energy density, adequate protein content, high protein quality and availability, adequate fat content, appropriate fat quality, content of some animal source foods, low content of antinutrients, low risk of contamination, acceptable taste and texture, cultural acceptability, easy to prepare, affordable and available [7]. Most of these dietary attributes are addressed in the account which follows. Golden has pointed out that ordinarily 


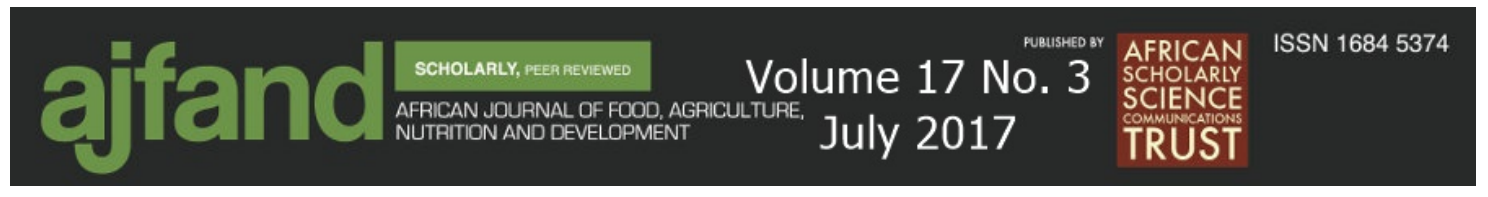

children with moderate malnutrition (stunting or wasting) have been consuming a diet deficient in many nutrients, both types I and II, and that sufficient quantities of all essential nutrients are needed for full health [6]. Recommendations by Golden and by Michaelsen et al. in Table 2 and by Golden for the micronutrient levels in Table 3 are for malnourished children $[6,7]$. These values specify the requirements for normal growth at an accelerated rate [6].

The purpose of this study is to present nutritional and other relevant quality characteristics of nine experimental weaning food mixtures and their acceptability assessment by Zambian mothers.

\section{METHODS AND MATERIALS}

\section{Experimental design}

An incomplete block design was developed for the evaluation of nine experimental weaning food blends, in comparison to a control mixture, by Zambian mothers (or guardians). Each mother in the given study group judged three different treatment blends plus the control blend only once. Therefore, the incomplete design consisted of 9 treatments taken 3 at a time blocking on evaluator (mother/guardian). The weaning blends were evaluated by alternate groups of mothers as cooked porridges or as ingredient sets of uncooked blend components. In the cooked porridge division of the study, 127 caregivers of children ranging from 6 to 27 months participated. For evaluating the suitability of sets of uncooked blend ingredients, 140 caregivers of children ranging in age from 5 to 30 months took part.

Four high population-density residential areas in the city of Lusaka, Zambia were selected randomly as sites for the study. Central Statistical Office personnel in Lusaka were sent into these four areas to list mothers in randomly selected subareas who had weaning age children. Random selection was again employed to assign mothers from these comprehensive lists to survey groups (porridges or ingredient sets). A few children fell outside the target child weaning age category (6 to 24 months) for surveyed mothers. Occasionally, it was necessary to randomly select a substitute mother for one unable to make the appointment.

The same general procedure used for judging ingredient sets was also used for evaluating cooked porridges. Cooked porridges and sets of uncooked ingredients were evaluated by different judges at different times at the same geographical sites. At each session, three of the nine blend treatments plus the control blend only once were judged by each mother. Three digit random number codes were generated for different samples. A random number sequence was specified for the order of uncovering and presentation of the four samples to each different judge. For the portion of the study evaluating cooked porridges, 9 to 13 mothers participated per evaluation session; in the appraisal of uncooked sets of blend ingredients, there were 9 to 15 participants per session. The total number of individuals surveyed per treatment (nine experimental blends) ranged from 38 to 45 for the cooked porridges and from 42 to 52 for the uncooked ingredient sets. The total persons evaluating the four control porridge 


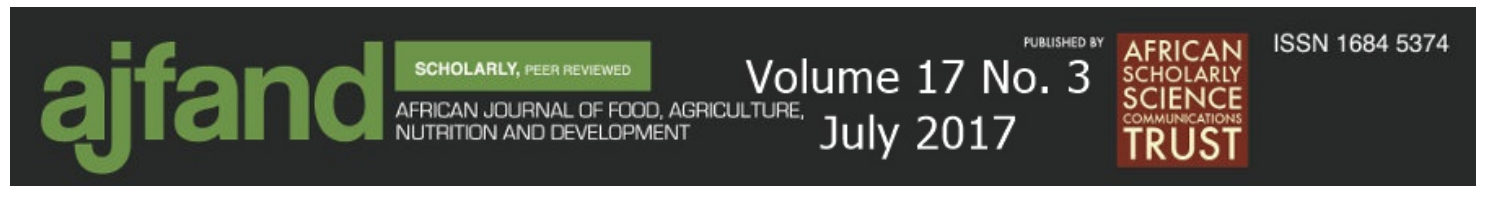

characteristics ranged from 125 to 127 , and 140 judged the two categories of acceptability for the control ingredient set.

\section{Selection of blends for assessment by mothers}

A number of different weaning blend formulations were first developed by the computer-optimization procedure described by Hayes et al. designed to meet the energy and protein needs of young children at least cost [8]. Nonfat dry milk currently needs to be imported. Otherwise, blend commodities are available in Lusaka markets, at least at some season(s) of the year, or are procurable within Zambia. Some processing is required for most of the market commodities. Such procedures may be carried out at the home or by means of community level adaptive technology equipment. Commodity restraints imposed on the computer program to produce alternative formulations included: mother preferred versus all available market ingredients, ingredients available during certain seasons, use or nonuse of nonfat dry milk, and levels of particular ingredients likely to be available during drought conditions (millet, sorghum). The commodities in the reported weaning food blends are listed as follows, with their range of months availability $($ January $=1 \ldots$ December $=12)$. These include maize meal (1-12), rice (2-10), sorghum (3-10), millet (3-10), groundnuts (3-10), soybeans (4-10), bambara nuts (4-12), cowpeas (1-10), nonfat dry milk (1-12), kapenta (3-10), sugar (1-12) and cooking oil (1-12). Of these, those selected by Lusaka mothers in an earlier study as being among the best foods ("mother preferred") to feed babies, included maize meal, rice, groundnuts, nonfat dry milk, kapenta, sugar and cooking oil [9]. Each blend was computer-formulated at minimized cost under the particular imposed constraints [8]. Seasonal availability of constituent commodities was always one of the constraints. For certain formulations, a constraint for an absorbed amino acid score above the minimum was imposed. This raised the blend cost, but was allowed to possibly enhance sensory and general child suitability acceptance. Otherwise all blends were formulated to meet recommended nutritional standards cited in Hayes et al. [8].

The mixture designated as the control/target blend (no. 10) contained only white maize meal (90\% extraction) and nonfat dry milk as principal ingredients; it most closely resembled in overall characteristics white maize meal alone, the traditional porridge commodity, yet was nutritionally comparable to the other blends evaluated. Formulations for the ten blends are listed in Table 1.

\section{Blend preparation and laboratory testing}

Table 1 describes the commodity composition of the ten weaning food blends evaluated by mothers. These mixtures were intended for preparation in the home or community. Home procedures required by individual commodities after purchasing in the market, as well as chemical analytical procedures have been described by Hayes et al. [8]. Not included in the previous study, pearl millet (Pennisetum glaucum) was proximately analyzed as above [8]. Amino acid analyses were conducted according to Pellett and Young [10]. Dehulling in this case was carried out using equipment manufactured by Rural Industries Innovation Centre (RIIC), Kanye, Botswana. Cleaning and roasting operations for the millet were accomplished by home procedures. Roasting times for all commodities were 15 minutes. 


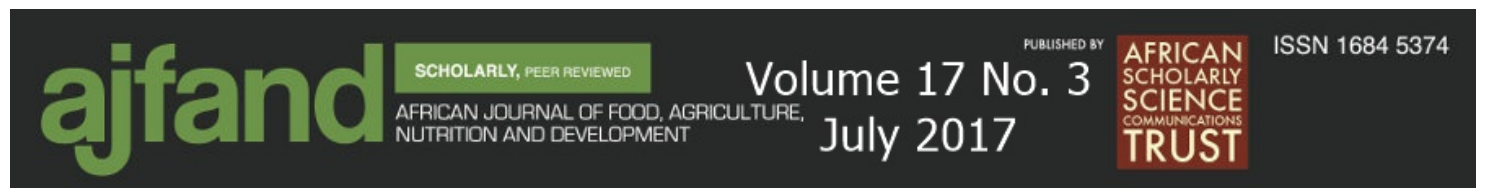

Roasted soy sample was tested for urease activity [8]. A Brookfield model RVT viscometer at $50 \mathrm{rpm}$ with a no. 5 or 7 spindle was used to determine the blend /water quantities necessary to produce cooked porridge viscosities in the range of 2800-3200 cps [8].

\section{Presenters to Mothers}

The individuals who presented samples to mothers and who recorded responses were chosen from among area nutritionists and health professionals, and then given preparatory training. Mothers participating in each assessment session were given a gift packet of high energy protein supplement (HEPS), which was provided by the World Food Programme. Rating descriptions for the five point hedonic scales used in the cooked porridge and uncooked ingredient set evaluations were provided in the Zambian dialects of Nyanja, Bemba, Tonga, and Lozi, as well as in English. Each interview was conducted in the language of choice for the responder.

Responders provided the following identifying information to interviewers. The most easily understood language as declared by respective participants was Nyanja, 47.2\%; Bemba, 41.6\%; Tonga, 4.1\%; Lozi, 3.0\%; English, 2.2\%. The province or country of birth of those evaluating the blends was Lusaka, 39.7\%; Copperbelt, 17.2\%; Northern, 10.1\%; Eastern, 9.7\%; Central, 8.6\%; Southern, 7.1\%; Western, 4.1\%; Luapula, 1.5\%; Northwestern, 0.7; Zimbabwe, 0.7\%; Democratic Republic of the Congo, 0.4\%. The mean educational grade level of these participants was $6.95 \pm 0.15$ S.E.; the grade level range was 0 to 12 .

\section{Cooked porridge evaluation}

The participant was told that the four porridges she was about to evaluate had been prepared from a mixture of ingredients and that all of the porridges were nutritious for her child. The cooked porridges, prepared by project personnel at testing sites, were served to mothers at approximately $40{ }^{\circ} \mathrm{C}$ in the same viscosity range of $2800-3200$ cps. The four porridges were presented to the respondent, each in turn, according to the predetermined random order listing. A cardboard tray enclosed four cardboard cups, each of which contained a glass beaker with a given porridge. Lids were provided for the cardboard cups. Also provided was a separate spoon for each porridge, a serviette, and a cup of water for mouth rinsing. The cup lid was removed only before the mother evaluated a particular sample; and the lid was replaced after the evaluation of that sample.

Each mother was handed a five point hedonic scale card in a suitable language. The interviewer explained the meaning of each facial expression. The hedonic ratings were as follows: 1 = dislike a lot; $2=$ dislike a little; $3=$ neither like nor dislike; $4=$ like a little; $5=$ like a lot. A mother was asked to rate each porridge with respect to: how it looked (appearance); flavor (taste and odor); how it felt in the mouth (grittiness/smoothness), considering that the porridges had been made to about the same consistency for babies of a certain age; and how suitable, in general, she considered it to be for feeding her child. In addition, the evaluator was asked if she would like to make any comments concerning the characteristics or the quality of each 


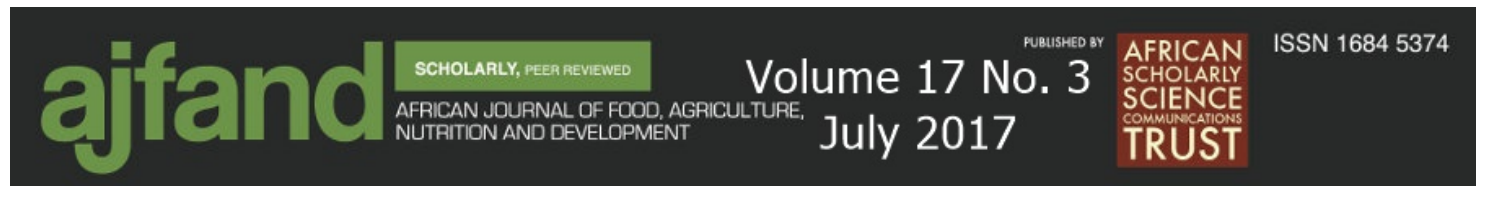

porridge. Pelto et al. have pointed out the value of such open-ended questions in that they qualitatively assist in reflecting beliefs, attitudes and behaviors [11]. The interviewer recorded responses to these questions and to certain other inquiries related to ethnic and educational background, and general information.

\section{Uncooked porridge ingredients evaluation}

Each mother was told that she would be asked to give her opinion about four sets of ingredients, each of which could be made into a porridge which would promote good health in her child. Inside a cardboard tray were four aluminum foil-covered containers, each of which contained a set of beakers with the individual ingredients in the proportion used in that given blend.

The respondent was then asked how inclined and willing she would be to prepare and use each set of ingredients for her child's porridge, with respect to two factor groupings. These were first, ingredient composition: the types and relative amounts of commodities in the given set. Secondly, were utilization elements of expense, time involved, and ease in preparing the given set of ingredients shown.

The scoring of the uncooked porridge ingredients on a hedonic scale was similar to the five point hedonic scale card used for the cooked porridge evaluation. The interviewer in like manner explained the meaning of the various facial expressions, in this case with the accompanying inclination/willingness to adopt designations.

The four sets of porridge ingredients were presented to the respondent; each set, in turn, according to the given random order listing. The foil cover of the tray was removed just before the mother evaluated that set of ingredients. The cover was then replaced before the next set was shown.

As appropriate for each set, the interviewer instructed the respondent with respect to the following particulars. In practice, the mother would have to clean, dehull, and roast some ingredients. Equipment would be provided in the community to dehull millet and grind this and other ingredients at an affordable price.

Again, mothers were asked if they had further comments regarding individual ingredient sets. The interviewer recorded responses to the set evaluation questions, voluntary comments, and to general information queries.

\section{Blend comparisons with quality criteria}

In Tables 1 through 3, macronutrient and micronutrient characteristics of the experimental blends are reported. In Table 2, comparison is made regarding macronutrients with Codex Alimentarius guidelines and with recommendations for moderately nourished children as proposed by Golden and by Michaelsen et al. [6, 7, 12]. In Table 3, estimated micronutrient levels are compared with proposed levels for malnourished children [6]. Study blend formulations, as specified in Hayes et al. were based on human milk protein as the amino acid scoring pattern, as was recommended by an FAO/WHO/UNU Expert Consultation [8, 13]. Protein quality is reported in terms of the current protein digestibility-corrected amino acid score (PDCAAS) [14]. 


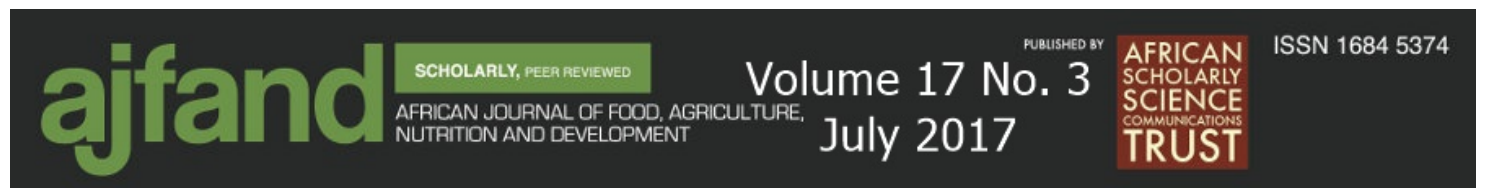

Estimation of micronutrient and dietary fiber contributions have been determined using the International Minilist approach [15]. Provision has been made to add extra oil to porridges upon serving. This practice has been carried out for U.S. Government type mixtures such as corn-soy blend to reduce rancidity development during storage [7].

\section{Statistical analysis}

Both for mothers' judgments concerning cooked porridge characteristics (Table 4) and for ingredient set suitability factors (Table 5), comparisons of blends 1 through 9 were made with parallel responses for blend 10 (control). Analysis of variance (ANOVA) was performed on the differences between scores (experimental blend minus control blend) which can be treated itself as a normally distributed response. Such a difference indicates how a given hedonic scale experimental blend score differs from the corresponding hedonic control score. A positive difference signifies a higher score, and a negative difference signifies a lower score than the control.

Treatment comparisons were made based on this analysis of variance, and statistical significance was declared at $p=0.1,0.05$, and 0.01 levels. These three significance levels were chosen instead of one level to present a more informative indication on how strong the significance was among closely rated blends. In Table 6, which deals with strengths of association between quality factors, the listed values represent averages over blends 1 through 9 of above described differences in scores ratings. These average listings apply to the respective cooked porridge factors or to the respective ingredient set factors. Significance of association between the factors was tested using Pearson correlation coefficient.

\section{Blend costs}

Zambian commodity 2010 market costs were obtained, blend costs calculated, then translated into U.S. dollar equivalents per kg dry basis. It was necessary to obtain an imported price for nonfat dry milk in 2010. This commodity was not at that time available locally.

\section{RESULTS}

\section{Blend nutritional characteristics in relation to recommended criteria}

Macronutrient/energy values are listed for the described blends in Table 1 and compared to recommendations in Codex Alimentarius, Golden, and Michaelsen et al. in Table $2[6,7,12]$. Estimated micronutrient levels are presented in Table 3 and compared to recommendations by Golden and FAO $[6,15]$. It is noted in Table 1 that blends 2, 6 and 7 have an especially low energy density at the start of weaning. Energy density of constituted porridge depends upon characteristics of the particular mix of ingredients in the blend, and can be quite different among blends having the similar $\mathrm{kcal} / \mathrm{g}$ dry blend values. Zambian project personnel recommended a $3000 \mathrm{cps}$ viscosity at $40{ }^{\circ} \mathrm{C}$ (a pourable gruel) as a consistency suitable for feeding a small child. In comparison of listed porridge energy values for start of weaning with higher recommended table values for malnourished children, note that as infants become older they can ingest thicker, more energy dense porridges. Provision of additional oil at the 


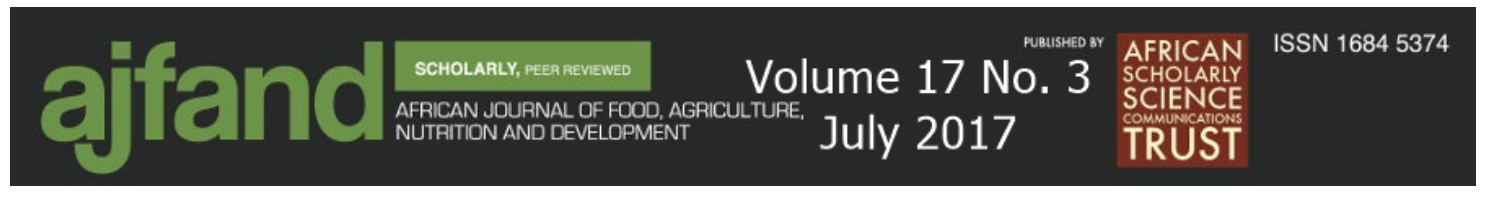

time of food service follows the practice of keeping lower levels in stored mixtures to minimize rancidity development [7].

Golden points out with respect to Table 2 recommended levels that when special complementary foods are being formulated to treat moderate malnutrition, it is assumed that such foods can be fortified with specific nutrients to achieve optimum nutrition density [6]. Hence, further complementation of study mixtures is expected.

\section{Statistical assessment of cooked porridge and uncooked ingredient set quality factors}

In reviewing results of statistical comparisons of Table 4, 5 and 6 , particular comparisons stand out. In Table 4, it is seen that porridge 6 is given a much poorer overall appraisal in comparison with blends 1 through 5, 8 and 9, and to a lesser extent with blend 7. Table 5 shows the very poor overall assessments given to mixture 8 in relation to ingredient sets 1 through 5 and 9 . The comparison is less significant between blend 6 and 7 with 8 . It is revealed in Table 6 that all cooked porridge quality factors are associated with each other at $p \leq 0.01$ level, and that the two ingredient set rating categories are also associated with each other at $\mathrm{p} \leq 0.01$ level.

\section{Blend costs}

Table 7 shows that the most expensive blend was number 4, with a substantial rice and nonfat dry milk content. Among the reasonably accepted blends, the least expensive mixture was number 3, containing a high level of maize meal, moderately low nonfat dry milk and moderate soy levels.

\section{Comparative suitability of evaluated weaning blends}

Table 7 represents an integration of subset study results and points to a number of factors which should be considered in weaning blend suitability.

Table 7 also presents qualitative notations on the proportion of positive to negative (or unclear) voluntary comments expressed on features of cooked porridges and of uncooked ingredient sets. Included in these ratios, in addition to overall expressions of approval or disapproval, specific comments were made on characteristics such as taste, smell, flavor, color, favoring or not favoring certain ingredients, unfamiliarity with certain foods, willingness to try a certain commodity, affordability or unaffordability of a certain food component, need for a commodity to be donated, a perceived health benefit, and need for preparation instructions. Blend 5 porridge had an unusually high ratio of voluntary favorable comments on child suitability. Milk was especially quite often cited as an expensive ingredient. Unfavorable porridge taste and smell were likely associated with the dark kapenta component of blends 2 and 6.

\section{DISCUSSION}

Parsonage and Clark have noted that a family's nutritional needs are usually met principally through the mother [16]. The statistical analyses and the volunteer comments of the results provide insights, to those promoting improved national child health measures concerning the constitution of weaning mixtures, practical 


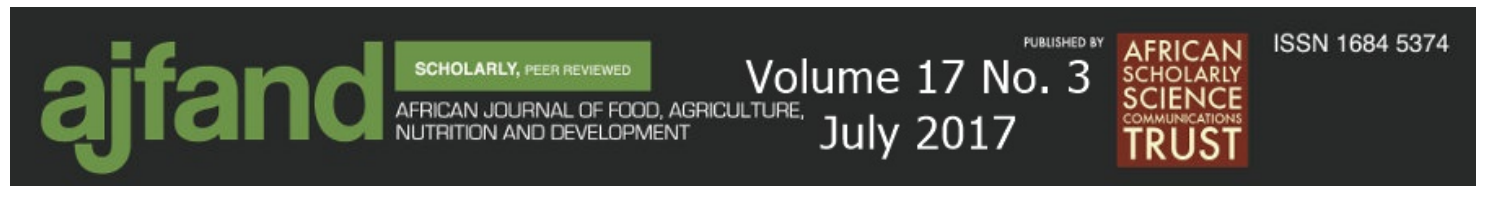

implementation measures and specific educational efforts which are likely to enhance adoption.

First impressions of quality are seen to be important in these types of evaluations. In each instance, for porridges or ingredient sets, there is an obvious carry over effect in quality rating from the first rated factor to those subsequently evaluated, per Table 6 . Stone et al. have described this as a halo effect which is more often involved in tests involving consumers, particularly when they are asked to respond to a number of questions [17].

\section{Pertinent influences which can modify study results}

Maize meal is the commodity of culturally preferred porridge in Zambia. In time of drought with accompanying low maize yields, the maize meal component for a given type porridge could be a factor in blend choice. Each of blends 6, 7, and 8 contains much less maize meal than the other mixtures. Millet or sorghum, which are more drought resistant, have replaced maize to different degrees in these mixtures.

As noted above, for porridges and for ingredient sets there is a marked carry over in statistically significant associated quality ratings from the first rated factor to those subsequently assessed. Mothers' lifetime acquaintance with the traditional white maize meal may well have influenced this result.

The level of nonfat dry milk required in a formulation may be a particular cost factor in choice of a weaning mixture. The relative market availability of different blend commodities at any given time will also determine blend costs. The promotion of home gardening for some commodities is a possible way of reducing mixture costs. Objections associated with preparation inconvenience, and indirectly costs, for some blends may be offset by a cooperative community effort to process certain ingredients. International food donations in times of food emergency could influence the selection of blend type. For example, relief donations of rice and nonfat dry milk could offset the high cost objection to blend 4 .

Educational efforts may alter acceptability responses by mothers. Guptill et al. found that mothers' perception of the complexity of a weaning food recipe is reduced by giving them an opportunity to actually prepare the food themselves during an intervention [18]. An earlier survey of mothers indicated that kapenta was considered a good weaning food [9]. However, this response was most likely based on the contemporary nutrition education teaching that this commodity has high nutritional value. The present study reflects the fact that kapenta actually imparted an unappealing odor and color when incorporated into a weaning mixture.

\section{Acceptability of the designated control blend (no. 10)}

Since all of the nine experimental weaning food mixtures were compared to the designated control/target blend (no. 10), it is of definite interest to know how acceptable this control was to mothers. The present control blend (no. 10), with additional fortification of vitamins and minerals, was used in the regimen to evaluate short-duration exclusive breastfeeding as a means of reducing human 


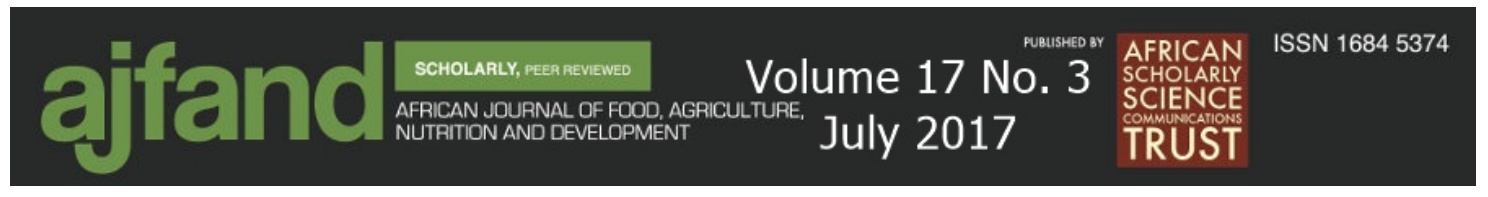

immunodeficiency virus (HIV) transmission in infant feeding for the Zambia Exclusive Breastfeeding Study (ZEBS) [19, 20]. As reported for ZEBS, "Our qualitative experience with the blend was that it was highly desirable and extensively adopted by the mothers and children in our study"; Donald M. Thea, M.D., principal investigator, ZEBS; August 28, 2014. This independent report points to the high mother acceptability of the control blend used in the current study.

\section{CONCLUSION}

This weaning food investigation features the incorporation of a number of considerations which should jointly be taken into account before particular mixtures are promoted to the public. The present survey was preceded by an assessment for the specific community of nutritional need and commodity preferences and by determination of computer-optimized blend formulas of indigenous food components, prepared by local methods $[8,9]$. Testing with mothers involved not only their organoleptic perceptions, but their inclination to use individual food ingredients, judgment on practical matters such as expense and ease and time of preparation. In addition, respondents were permitted to offer opinions beyond the structured inquiries, which brought out compelling concerns. Thorough nutritional comparison of blend nutritional values with recommended standards were presented. Relative costs of the mixtures were demonstrated. Such a broad-based evaluation assists in a more accurate prediction as to which weaning mixtures would likely be most acceptable by the given community and be recommended for possible adoption.

\section{RECOMMENDATIONS}

The following weaning mixtures are recommended for priority follow-through toward possible community promotion Listings with respect to blend number, principal components and percentages are: No. 5, maize meal (57.7\%), bambara nuts (14.6\%), nonfat dry milk (21.7\%); No. 3, maize meal (62.4\%), soybeans $(7.6 \%)$, nonfat dry milk (18.4\%); No. 10 - Control, maize meal (62.2\%), nonfat dry milk (26.1\%). Further recommendation details are presented in Table 7.

\section{ACKNOWLEDGEMENTS}

Special appreciation is expressed to the following individuals for their valuable assistance in this study: Deborah L. Boykin, USDA, ARS, Mid-South Area, U.S.A, experimental design and analysis; Gladys C. Kabaghe (retired), nutritional scientist, National Institute for Scientific and Industrial Research, Zambia; James I. Wadsworth (retired), USDA, ARS, Southern Region Research Center, USA., linear programming; Jeffrey E. Brotherton, Converse College, USA., amino acid analysis; and a number of nutritionists, food scientists, health professionals and technicians in Zambia who assisted in various phases of the effort. Partial funding was provided by United States Government Fulbright and World Health Organization grants. The Government of Zambia substantially supported the project via the National Institute for Scientific and Industrial Research.

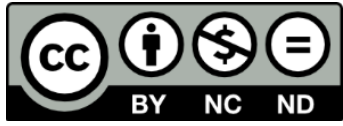




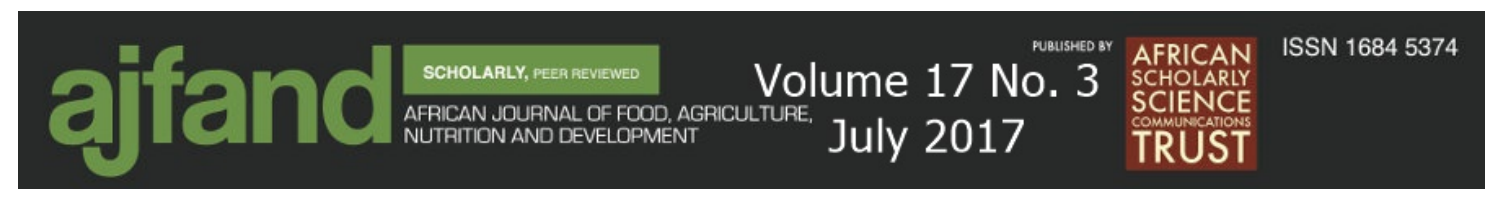

Table 1: Commodity Composition and Macronutrient/Energy Parameters for Experimental Weaning Blends

\begin{tabular}{|c|c|c|c|c|c|c|c|c|c|}
\hline $\begin{array}{c}\text { Blend } \\
\text { No. }\end{array}$ & $\begin{array}{c}\text { Blend Composition } \\
\% \text { Commodities in Mixture }^{\mathrm{a}}\end{array}$ & $\begin{array}{c}\text { Dry Blend } \\
\text { Energy } \\
\text { Density } \\
\text { Kcal/g d.b. } \\
\text { (+ Oil to } 35 \%^{\text {Fat kcal) }}\end{array}$ & $\begin{array}{c}\text { Porridge } \\
\text { Energy } \\
\text { Density } \\
\text { Kcal/g of food } \\
\text { at start of } \\
\text { weaning } \\
\text { (+ Oil to } 35 \% \\
\text { Fat kcal) }\end{array}$ & $\begin{array}{c}\% \\
\begin{array}{c}\text { Total Energy } \\
\text { from }\end{array} \\
\text { Protein } \\
\text { (+ Oil to } 35 \% \\
\text { Fat kcal) }\end{array}$ & $\begin{array}{l}\text { Protein } \\
\text { PDCAAS }^{\mathrm{g}} \\
\text { Infant } \\
0-0.5 \text { yrs } \\
\text { (Lim. a.a.) }^{\mathrm{h}}\end{array}$ & $\begin{array}{l}\text { PDCAAS } \\
\text { Preschool } \\
1-2 \text { yrs } \\
\text { (Lim. a.a.) }\end{array}$ & $\begin{array}{c}\% \\
\text { Total Energy } \\
\text { from } \\
\text { Fat } \\
\text { (+ Oil to } 35 \% \\
\text { Fat kcal) }\end{array}$ & $\begin{array}{c}\text { Crude } \\
\text { Fiber } \\
\% \text { d.b. } \\
\text { (+ Oil to } 35 \% \\
\text { Fat kcal) }\end{array}$ & $\begin{array}{c}\text { Dietary } \\
\text { Fiber }{ }^{1} \\
\% \text { d.b. } \\
\text { (+ Oil to } 35 \% \\
\text { Fat kcal) }\end{array}$ \\
\hline 1 & $\begin{array}{l}\text { Corn meal (57.8); Cowpeas, de- } \\
\text { hulled, roasted (8.8); NFDM } \\
\text { (21.8); Sugar (7.3); Oil (4.3) }\end{array}$ & $\begin{array}{c}4.2 \\
(4.8)\end{array}$ & $\begin{array}{c}0.65 \\
(0.85)\end{array}$ & $\begin{array}{c}15.0 \\
(11.7)\end{array}$ & $\begin{array}{c}84 \\
(\text { lys })\end{array}$ & $\begin{array}{c}92 \\
\text { (lys) }\end{array}$ & $\begin{array}{c}15.0 \\
(35.0)\end{array}$ & $\begin{array}{c}0.8 \\
(0.7)\end{array}$ & $\begin{array}{c}6.3 \\
(5.5)\end{array}$ \\
\hline 2 & $\begin{array}{l}\text { Corn meal (65.7); NFDM (20.3); } \\
\text { Kapenta, dried (2.7); } \\
\text { Sugar (7.2); Oil (4.1) }\end{array}$ & $\begin{array}{c}4.2 \\
(4.8)\end{array}$ & $\begin{array}{c}0.60 \\
(0.78)\end{array}$ & $\begin{array}{c}15.0 \\
(11.5)\end{array}$ & $\begin{array}{c}86 \\
\text { (lys) }\end{array}$ & $\begin{array}{c}94 \\
\text { (lys) }\end{array}$ & $\begin{array}{c}15.0 \\
(35.0)\end{array}$ & $\begin{array}{c}0.7 \\
(0.6)\end{array}$ & $\begin{array}{c}5.3 \\
(4.6)\end{array}$ \\
\hline 3 & $\begin{array}{l}\text { Corn meal (64.2); Soybeans, de- } \\
\text { hulled, roasted (7.6); NFDM } \\
\text { (18.4); Sugar (7.3); Oil (2.5) }\end{array}$ & $\begin{array}{c}4.2 \\
(4.8)\end{array}$ & $\begin{array}{c}0.66 \\
(0.86)\end{array}$ & $\begin{array}{c}15.0 \\
(11.7)\end{array}$ & $\begin{array}{c}73 \\
\text { (lys) }\end{array}$ & $\begin{array}{c}80 \\
\text { (lys) }\end{array}$ & $\begin{array}{c}15.0 \\
(35.0)\end{array}$ & $\begin{array}{c}0.9 \\
(0.8)\end{array}$ & $\begin{array}{c}6.0 \\
(5.2)\end{array}$ \\
\hline 4 & $\begin{array}{l}\text { Corn meal (38.2); Rice, polished, } \\
\text { roasted (21.9); NFDM (27.4); } \\
\text { Sugar (7.4); Oil (5.1) }\end{array}$ & $\begin{array}{c}4.2 \\
(4.8)\end{array}$ & $\begin{array}{c}0.68 \\
(0.89)\end{array}$ & $\begin{array}{c}15.0 \\
(11.3)\end{array}$ & $\begin{array}{c}90 \\
\text { (lys) }\end{array}$ & $\begin{array}{c}99 \\
\text { (lys) }\end{array}$ & $\begin{array}{c}15.0 \\
(35.0)\end{array}$ & $\begin{array}{c}0.6 \\
(0.5)\end{array}$ & $\begin{array}{c}3.2 \\
(2.8)\end{array}$ \\
\hline 5 & $\begin{array}{l}\text { Corn meal (52.7); Bambara nuts, } \\
\text { dehulled, roasted (14.6); NFDM } \\
\text { (21.7); Sugar (7.3); Oil (3.7) }\end{array}$ & $\begin{array}{c}4.2 \\
(4.8)\end{array}$ & $\begin{array}{c}0.68 \\
(0.89)\end{array}$ & $\begin{array}{c}15.1 \\
(11.7)\end{array}$ & $\begin{array}{c}83 \\
\text { (lys) }\end{array}$ & $\begin{array}{c}91 \\
\text { (lys) }\end{array}$ & $\begin{array}{c}15.0 \\
(35.0)\end{array}$ & $\begin{array}{c}1.1 \\
(0.9)\end{array}$ & $\begin{array}{c}6.1 \\
(5.4)\end{array}$ \\
\hline 6 & $\begin{array}{l}\text { Corn meal }(9.2) \text {; Millet dehulled, } \\
\text { roasted (67.8); Groundnuts } \\
\text { with skins (4.8); Kapenta, dried } \\
(9.8) \text {; Sugar (7.6); Oil }(0.8)\end{array}$ & $\begin{array}{c}4.2 \\
(4.8)\end{array}$ & $\begin{array}{c}0.55 \\
(0.72)\end{array}$ & $\begin{array}{c}14.9 \\
(12.2)\end{array}$ & $\begin{array}{c}63 \\
\text { (lys) }\end{array}$ & $\begin{array}{c}69 \\
\text { (lys) }\end{array}$ & $\begin{array}{c}14.9 \\
(35.0)\end{array}$ & $\begin{array}{c}0.6 \\
(0.5)\end{array}$ & $\begin{array}{c}7.1 \\
(6.1)\end{array}$ \\
\hline 7 & $\begin{array}{l}\text { Corn meal (33.4); Sorghum, de- } \\
\text { hulled, roasted (33.4); Soybeans, } \\
\text { dehulled, roasted (7.0); NFDM } \\
(16.5) \text {; Sugar (7.3); Oil (2.4) }\end{array}$ & $\begin{array}{c}4.2 \\
(4.8)\end{array}$ & $\begin{array}{c}0.58 \\
(0.76)\end{array}$ & $\begin{array}{c}15.0 \\
(11.8)\end{array}$ & $\begin{array}{c}65 \\
\text { (lys) }\end{array}$ & $\begin{array}{c}71 \\
\text { (lys) }\end{array}$ & $\begin{array}{c}15.0 \\
(35.0)\end{array}$ & $\begin{array}{c}0.9 \\
(0.8)\end{array}$ & $\begin{array}{c}6.7 \\
(5.9)\end{array}$ \\
\hline
\end{tabular}




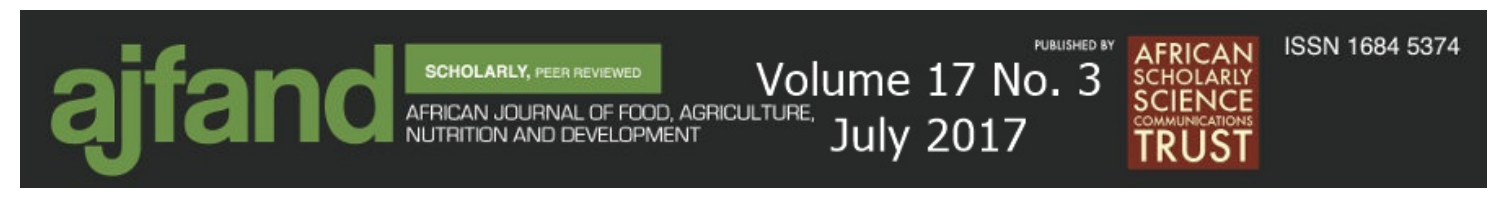

\begin{tabular}{|c|c|c|c|c|c|c|c|c|c|}
\hline $\begin{array}{l}\text { Blend } \\
\text { No. }\end{array}$ & $\begin{array}{c}\text { Blend Composition } \\
\% \text { Commodities in Mixture }\end{array}$ & $\begin{array}{l}\text { Dry Blend } \\
\text { Energy } \\
\text { Density } \\
\text { Kcal } / \text { g d.b. } \\
\text { (+ Oil to } 35 \% \\
\text { Fat kcal) }^{\mathrm{e}}\end{array}$ & $\begin{array}{c}\text { Porridge } \\
\text { Energy } \\
\text { Density } \\
\text { Kcal/g of food } \\
\text { at start of } \\
\text { weaning } \\
\text { (+ Oil to } 35 \% \\
\text { Fat kcal) }\end{array}$ & $\begin{array}{c}\% \\
\text { Total Energy } \\
\text { from } \\
\underline{\text { Protein }} \\
\text { (+ Oil to } 35 \% \\
\text { Fat kcal) }\end{array}$ & $\begin{array}{l}\text { Protein } \\
\text { PDCAAS } \\
\text { Infant } \\
0-0.5 \text { yrs } \\
{\text { (Lim. a.a. })^{\mathrm{h}}}^{\text {(Lim }}\end{array}$ & $\begin{array}{l}\text { PDCAAS } \\
\text { Preschool } \\
1-2 \text { yrs } \\
\text { (Lim. a.a.) }\end{array}$ & $\begin{array}{c}\% \\
\text { Total Energy } \\
\text { from } \\
\text { Fat } \\
\text { (+ Oil to } 35 \% \\
\text { Fat kcal) }\end{array}$ & $\begin{array}{l}\text { Crude } \\
\text { Fiber } \\
\% \text { d.b. } \\
\text { (+ Oil to } 35 \% \\
\text { Fat kcal) }\end{array}$ & $\begin{array}{l}\text { Dietary } \\
\text { Fiber } \\
\% \text { d.b. } \\
\text { (+ Oil to } 35 \% \\
\text { Fat kcal) }\end{array}$ \\
\hline 8 & $\begin{array}{l}\text { Corn meal (27.0); Millet, de- } \\
\text { hulled, roasted (27.0); Soy- } \\
\text { beans, dehulled, roasted (7.9); } \\
\text { Bambara nuts, dehulled, } \\
\text { roasted (16.7); NFDM (12.4); } \\
\text { Sugar (7.5); Oil (1.5) }\end{array}$ & $\begin{array}{c}4.2 \\
(4.8)\end{array}$ & $\begin{array}{c}0.65 \\
(0.85)\end{array}$ & $\begin{array}{c}15.0 \\
(12.0)\end{array}$ & $\begin{array}{c}62 \\
\text { (lys) }\end{array}$ & $\begin{array}{c}68 \\
\text { (lys) }\end{array}$ & $\begin{array}{l}15.0 \\
(35.0)\end{array}$ & $\begin{array}{c}1.2 \\
(1.0)\end{array}$ & $\begin{array}{c}6.9 \\
(6.1)\end{array}$ \\
\hline 9 & $\begin{array}{l}\text { Corn meal (59.5); Bambara nuts, } \\
\text { dehulled, roasted (4.2); NFDM } \\
\text { (24.9); Sugar (7.3); Oil (4.1) }\end{array}$ & $\begin{array}{c}4.2 \\
(4.8)\end{array}$ & $\begin{array}{c}0.69 \\
(0.90)\end{array}$ & $\begin{array}{c}15.0 \\
(11.5)\end{array}$ & $\begin{array}{c}85 \\
\text { (lys) }\end{array}$ & $\begin{array}{c}94 \\
\text { (lys) }\end{array}$ & $\begin{array}{c}15.0 \\
(35.0)\end{array}$ & $\begin{array}{c}0.8 \\
(0.7)\end{array}$ & $\begin{array}{c}5.8 \\
(5.1)\end{array}$ \\
\hline $\begin{array}{c}10 \\
\mathrm{Ctrl}^{\mathrm{c}}\end{array}$ & $\begin{array}{l}\text { Corn meal (62.2); NFDM } \\
\text { (26.1); Sugar (7.3); Oil (4.4) }\end{array}$ & $\begin{array}{c}4.2 \\
(4.8)\end{array}$ & $\begin{array}{c}0.71 \\
(0.93)\end{array}$ & $\begin{array}{c}15.0 \\
(11.4)\end{array}$ & $\begin{array}{c}87 \\
\text { (lys) }\end{array}$ & $\begin{array}{c}95 \\
\text { (lys) }\end{array}$ & $\begin{array}{c}15.0 \\
(35.0)\end{array}$ & $\begin{array}{c}0.7 \\
(0.6)\end{array}$ & $\begin{array}{c}5.0 \\
(4.4)\end{array}$ \\
\hline
\end{tabular}

a. Percent "as is" - including normal moisture

b. NFDM = nonfat dry milk

c. Ctrl $=$ control blend

d. $d . b .=$ dry basis

e. Oil which can be added when food mixtures are prepared to serve. A higher oil content in blend formulations increase the likelihood ofrancidity development upon storage

f. Energy densities for cooked porridges made from formulated mixtures to exhibit a viscosity at $40{ }^{\circ} \mathrm{C}$ within the target range of 2800 -3200 cps. The addition of oil to $35 \%$ fat kcal raises the densities of the initial consistencies above the caloric density of breast milk $(0.7 \mathrm{kcal} / \mathrm{g})$

g. PDCAAS = protein digestibility corrected amino acid score. Amino acid scoring patterns are provided by the World Health Organization for infants 0 to 0.5 yrs. and for preschool children 1-2 yrs. [14]

h. Lim. a.a = limiting amino acid in the mixture

i. Dietary fiber values have been estimated by using principally the International Minilist (IML) together with certain more applicable values from other databases [15, $21-24]$ 


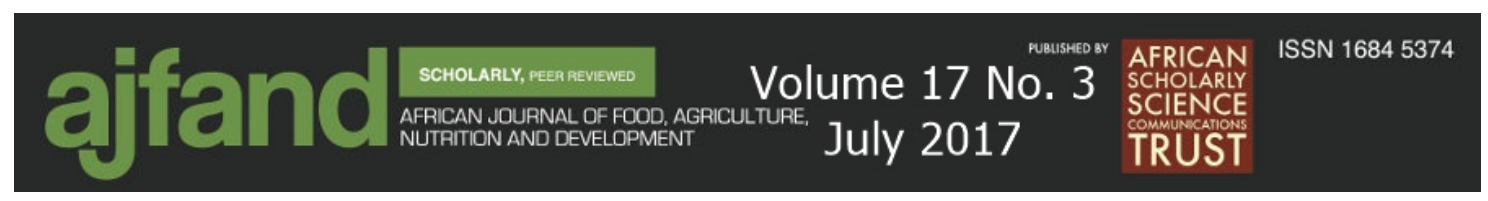

Table 2: Comparison of Macronutrient/Energy Parameters for Experimental Weaning Blends with Guidelines of Codex Alimentarius and Other Literature References

\begin{tabular}{|c|c|c|c|c|}
\hline Criterion & $\begin{array}{r}\begin{array}{c}\text { Experimental Blends Parameter } \\
\text { Ranges }\end{array} \\
\text { (+ Oil to } 35 \% \text { Fat Kcal })^{\mathrm{c}}\end{array}$ & $\begin{array}{c}\text { Codex Alimentarius } \\
\text { CAC/GL 08-1991 } \\
\text { Guidelines on Formulated } \\
\text { Supplementary Foods for Older } \\
\text { Infants and Young Children } \\
\end{array}$ & $\begin{array}{l}\text { Proposed Recommended } \\
\text { Nutrient Densities for } \\
\text { Moderately Malnourished } \\
\text { Children } \\
\text { (M. H. Golden } \text { ) } \\
\end{array}$ & $\begin{array}{l}\text { Proposed Nutritional Qualities of Relevant } \\
\text { Foods and Ingredients to Meet the Needs of } \\
\text { Moderately Malnourished Children } \\
\text { (K.M. Michaelsenet al. }{ }^{\mathrm{g}} \text { ) }\end{array}$ \\
\hline $\begin{array}{c}\text { Energy Density } \\
\text { (Units as designated) }\end{array}$ & 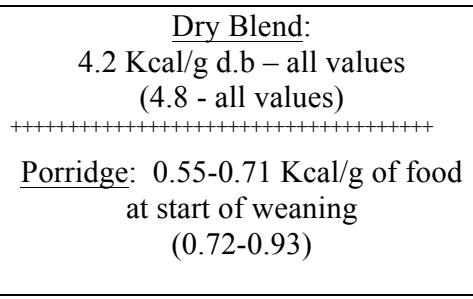 & $\frac{\text { Dry Blend }}{\geq 4.0 \mathrm{Kcal} / \mathrm{g} \text { d.b. }}$ & ( & $\begin{array}{c}\mathrm{Kcal} / \mathrm{g} \text { of food as served } \\
\text { Infants and young children with stunting: } 1.0- \\
1.50 \\
\text { Children with moderate wasting: } \\
1.50-2.50 \\
\text { A high energy density can be attained by } \\
\text { reducing the water content of the food and by } \\
\text { adding oils or sugar. } \\
\end{array}$ \\
\hline $\begin{array}{l}\% \text { Total Energy } \\
\text { from } \\
\text { Protein } \\
\end{array}$ & $\begin{array}{c}14.9-15.1 \\
(11.3-12.2)\end{array}$ & $x 15$ & 10.4 & $\begin{array}{l}\text { Aim for } \approx 12 \text {, taking into account that a food } \\
\text { supplement would not constitute the whole diet } \\
\text { for children with moderate malnutrition: } \# 15\end{array}$ \\
\hline $\begin{array}{c}\text { Protein Quality } \\
\text { (Units as designated) }\end{array}$ & $\begin{array}{c}\text { PDCAAS }^{\mathrm{d}} \\
\text { Infant } 0-0.5 \text { yrs. } \\
62-90 \\
++++++++++++++++++++++ \\
\text { PDCAAS } \\
\text { Preschool 1-2 yrs. } \\
68-99 \\
\end{array}$ & $\begin{array}{l}\text { Digestibility Corrected } \\
\text { Amino Acid Score } \\
70 \% \text { of that for casein } \\
(\geq 70 \text { PDCAAS }) \\
6 \text { mos- } 3 \text { yrs }\end{array}$ & $\geq 70 \%$ of reference protein & Aim for $>70$ to 80 PDCAAS \\
\hline $\begin{array}{l}\% \text { Total Energy } \\
\text { from } \\
\text { Fat }\end{array}$ & $\begin{array}{c}14.9-15.0 \\
(35)\end{array}$ & $\begin{array}{l}20-40 \text { desirable } \\
\text { Additional oil is recommended at } \\
\text { a. preparation for lower fat } \\
\text { formulations. }\end{array}$ & - & $\begin{array}{l}\text { For children with moderate malnutrition: } \\
\qquad \text { Aim for between } 35-45 \\
\qquad \geq 30 \\
\text { Lower fat blends may be distributed with } \\
\text { additional oil. }\end{array}$ \\
\hline $\begin{array}{c}\frac{\text { Crude Fiber }}{\mathrm{g} / 100 \mathrm{~g} \text { food }} \\
\text { d.b. }^{\mathrm{a}}\end{array}$ & $\begin{array}{c}0.6-1.2 \\
(0.5-1.0)\end{array}$ & - & - & - \\
\hline $\begin{array}{l}\frac{\text { Dietary Fiber }}{\mathrm{g} / 100 \mathrm{~g} \text { food }} \\
\text { d.b. }\end{array}$ & $\begin{array}{l}3.2-7.1 \\
(2.8-6.1)\end{array}$ & $\# 5$ & - & Keep as low as possible for infants up to 2 yrs. \\
\hline
\end{tabular}

a. d.b. = dry basis

b. Individual blend values for each of the listed criteria categories are presented in Table 1 


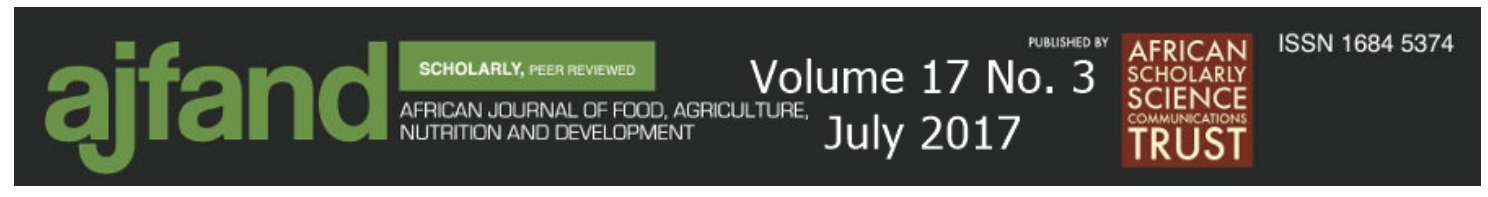

c. Additional oil can be added when food mixtures are prepared to serve. A higher oil content in blend formulations increases the likelihood of rancidity development during storage. Energy densities for cooked porridges from formulated mixtures were designed to exhibit a viscosity at $40{ }^{\circ} \mathrm{C}$ within the target range of 2800 - $3200 \mathrm{cps}$. The addition of oil to $35 \%$ fat kcal raises the densities of the initial consistencies above the caloric density of breast milk. $(0.7 \mathrm{kcal} / \mathrm{g})$

d. PDCAAS = protein digestibility corrected amino acid score. Amino acid scoring patterns are provided by the World Health Organization for infants 0 to 0.5 yrs. and for preschool children 1-2 yrs. [14]

e. Reference [12]

f. Reference [6]

g. Reference [7] 


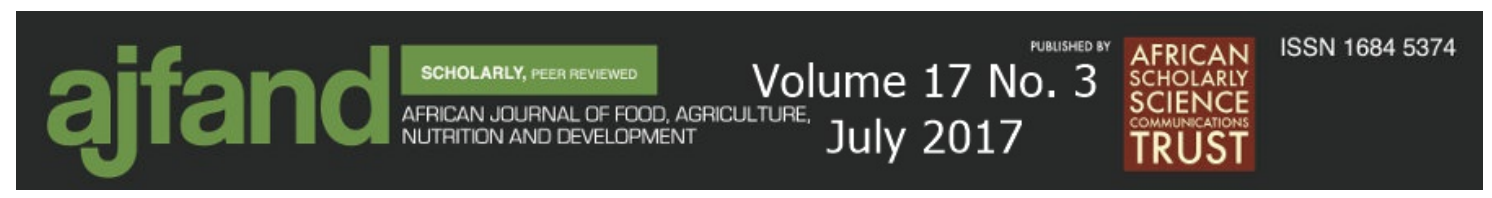

Table 3: Estimated Weaning Blend Micronutrient Levels ${ }^{\mathrm{a}}$ Per $1000 \mathrm{Kcal}$ and Their Percent RNIs ${ }^{\mathrm{b}}$ for Moderately Malnourished Children Consuming Fortified Supplementary Food: Rounded Values ${ }^{\text {c, }}$,

\begin{tabular}{|c|c|c|c|c|c|c|c|c|c|c|c|c|c|c|c|c|c|c|c|c|}
\hline $\begin{array}{c}\text { Blend } \\
\text { No. }\end{array}$ & $\begin{array}{c}\text { Vit A } \\
\text { mcg } \\
\text { RE }\end{array}$ & $\begin{array}{l}\text { Vit D } \\
\text { mcg }\end{array}$ & $\begin{array}{c}\text { Vit E } \\
\text { mg } \\
\alpha \text { TE }\end{array}$ & $\begin{array}{c}\text { Vit C } \\
\text { mg }\end{array}$ & $\begin{array}{c}\text { Thia } \\
\text { mg }\end{array}$ & $\begin{array}{c}\text { Ribo } \\
\text { mg }\end{array}$ & $\begin{array}{l}\mathrm{Nia} \\
\mathrm{mg}\end{array}$ & $\begin{array}{l}\text { Vit } \\
\text { B6 } \\
\text { mg }\end{array}$ & $\begin{array}{l}\text { Fol } \\
\text { mg }\end{array}$ & $\begin{array}{l}\text { Vit } \\
\text { B12 } \\
\text { mcg }\end{array}$ & $\begin{array}{c}\text { Pant } \\
\text { mg }\end{array}$ & $\begin{array}{l}\mathrm{Ca} \\
\mathrm{mg}\end{array}$ & $\begin{array}{c}\mathrm{P} \\
\mathrm{mg}\end{array}$ & $\begin{array}{l}\mathrm{mg} \\
\mathrm{mg}\end{array}$ & $\begin{array}{c}\mathrm{k} \\
\mathrm{mg}\end{array}$ & $\begin{array}{c}\mathrm{na} \\
\mathrm{mg}\end{array}$ & $\begin{array}{l}\mathrm{Fe} \\
\mathrm{mg}\end{array}$ & $\begin{array}{l}\mathrm{Zn} \\
\mathrm{mg}\end{array}$ & $\begin{array}{l}\mathrm{Cu} \\
\mathrm{mg}\end{array}$ & $\begin{array}{l}\mathrm{Mn} \\
\mathrm{mg}\end{array}$ \\
\hline 1 & $\begin{array}{c}8 \\
0.4 \% \\
\end{array}$ & $\begin{array}{c}0 \\
0 \% \\
\end{array}$ & $\begin{array}{c}2 \\
7 \% \\
\end{array}$ & $\begin{array}{c}5 \\
5 \% \\
\end{array}$ & $\begin{array}{c}0.8 \\
80 \% \\
\end{array}$ & $\begin{array}{c}1 \\
50 \% \\
\end{array}$ & $\begin{array}{c}3 \\
20 \% \\
\end{array}$ & $\begin{array}{c}0.7 \\
40 \% \\
\end{array}$ & $\begin{array}{r}190 \\
50 \% \\
\end{array}$ & $\begin{array}{c}2 \\
70 \% \\
\end{array}$ & $\begin{array}{c}3 \\
100 \% \\
\end{array}$ & $\begin{array}{r}780 \\
90 \% \\
\end{array}$ & $\begin{array}{r}1040 \\
120 \% \\
\end{array}$ & $\begin{array}{r}260 \\
90 \% \\
\end{array}$ & $\begin{array}{r}1540 \\
100 \% \\
\end{array}$ & $\begin{array}{l}330 \\
60 \% \\
\end{array}$ & $\begin{array}{c}4 \\
20 \% \\
\end{array}$ & $\begin{array}{c}6 \\
30 \% \\
\end{array}$ & $\begin{array}{c}0.5 \\
60 \% \\
\end{array}$ & $\begin{array}{c}0.9 \\
80 \% \\
\end{array}$ \\
\hline 2 & $\begin{array}{c}6 \\
0.3 \% \\
\end{array}$ & $\begin{array}{l}0.2 \\
2 \% \\
\end{array}$ & $\begin{array}{c}2 \\
8 \% \\
\end{array}$ & $\begin{array}{c}5 \\
5 \% \\
\end{array}$ & $\begin{array}{c}0.8 \\
80 \% \\
\end{array}$ & $\begin{array}{c}0.9 \\
50 \% \\
\end{array}$ & $\begin{array}{c}4 \\
20 \% \\
\end{array}$ & $\begin{array}{c}0.7 \\
40 \% \\
\end{array}$ & $\begin{array}{c}60 \\
20 \% \\
\end{array}$ & $\begin{array}{c}3 \\
100 \% \\
\end{array}$ & $\begin{array}{c}3 \\
90 \% \\
\end{array}$ & $\begin{array}{c}860 \\
100 \% \\
\end{array}$ & $\begin{array}{c}1040 \\
120 \%\end{array}$ & $\begin{array}{r}250 \\
80 \% \\
\end{array}$ & $\begin{array}{l}1400 \\
90 \%\end{array}$ & $\begin{array}{l}330 \\
60 \% \\
\end{array}$ & $\begin{array}{c}3 \\
20 \% \\
\end{array}$ & $\begin{array}{c}6 \\
30 \% \\
\end{array}$ & $\begin{array}{c}0.4 \\
40 \% \\
\end{array}$ & $\begin{array}{c}0.8 \\
70 \% \\
\end{array}$ \\
\hline 3 & $\begin{array}{c}7 \\
0.3 \% \\
\end{array}$ & $\begin{array}{c}0 \\
0 \% \\
\end{array}$ & $\begin{array}{c}2 \\
8 \% \\
\end{array}$ & $\begin{array}{c}4 \\
4 \% \\
\end{array}$ & $\begin{array}{c}0.8 \\
80 \% \\
\end{array}$ & $\begin{array}{c}1 \\
60 \% \\
\end{array}$ & $\begin{array}{c}4 \\
20 \% \\
\end{array}$ & $\begin{array}{c}0.8 \\
40 \% \\
\end{array}$ & $\begin{array}{c}100 \\
30 \% \\
\end{array}$ & $\begin{array}{c}2 \\
60 \% \\
\end{array}$ & $\begin{array}{c}3 \\
90 \% \\
\end{array}$ & $\begin{array}{c}690 \\
80 \% \\
\end{array}$ & $\begin{array}{c}980 \\
110 \% \\
\end{array}$ & $\begin{array}{c}310 \\
100 \% \\
\end{array}$ & $\begin{array}{r}1660 \\
100 \% \\
\end{array}$ & $\begin{array}{c}280 \\
50 \% \\
\end{array}$ & $\begin{array}{c}4 \\
20 \% \\
\end{array}$ & $\begin{array}{c}6 \\
30 \% \\
\end{array}$ & $\begin{array}{c}0.8 \\
90 \% \\
\end{array}$ & $\begin{array}{c}1 \\
90 \% \\
\end{array}$ \\
\hline 4 & $\begin{array}{c}7 \\
0.4 \% \\
\end{array}$ & $\begin{array}{c}0 \\
0 \% \\
\end{array}$ & $\begin{array}{c}1 \\
6 \% \\
\end{array}$ & $\begin{array}{c}6 \\
6 \% \\
\end{array}$ & $\begin{array}{c}0.6 \\
60 \% \\
\end{array}$ & $\begin{array}{c}1 \\
60 \% \\
\end{array}$ & $\begin{array}{c}3 \\
20 \% \\
\end{array}$ & $\begin{array}{c}0.6 \\
30 \% \\
\end{array}$ & $\begin{array}{c}50 \\
20 \% \\
\end{array}$ & $\begin{array}{c}2 \\
90 \% \\
\end{array}$ & $\begin{array}{c}4 \\
120 \% \\
\end{array}$ & $\begin{array}{c}910 \\
110 \% \\
\end{array}$ & $\begin{array}{r}1000 \\
110 \% \\
\end{array}$ & $\begin{array}{c}200 \\
70 \% \\
\end{array}$ & $\begin{array}{l}1470 \\
90 \% \\
\end{array}$ & $\begin{array}{c}390 \\
70 \% \\
\end{array}$ & $\begin{array}{c}2 \\
10 \% \\
\end{array}$ & $\begin{array}{c}5 \\
30 \% \\
\end{array}$ & $\begin{array}{c}0.3 \\
30 \% \\
\end{array}$ & $\begin{array}{c}0.4 \\
30 \% \\
\end{array}$ \\
\hline 5 & $\begin{array}{c}9 \\
0.5 \% \\
\end{array}$ & $\begin{array}{c}0 \\
0 \% \\
\end{array}$ & $\begin{array}{c}1 \\
6 \% \\
\end{array}$ & $\begin{array}{c}6 \\
6 \% \\
\end{array}$ & $\begin{array}{c}0.7 \\
70 \% \\
\end{array}$ & $\begin{array}{c}1 \\
50 \% \\
\end{array}$ & $\begin{array}{c}3 \\
20 \% \\
\end{array}$ & $\begin{array}{c}0.8 \\
40 \% \\
\end{array}$ & $\begin{array}{l}190 \\
60 \% \\
\end{array}$ & $\begin{array}{c}2 \\
70 \% \\
\end{array}$ & $\begin{array}{c}3 \\
100 \% \\
\end{array}$ & $\begin{array}{c}800 \\
100 \% \\
\end{array}$ & $\begin{array}{r}1050 \\
120 \% \\
\end{array}$ & $\begin{array}{c}250 \\
80 \% \\
\end{array}$ & $\begin{array}{c}1570 \\
100 \% \\
\end{array}$ & $\begin{array}{l}330 \\
60 \% \\
\end{array}$ & $\begin{array}{c}5 \\
30 \% \\
\end{array}$ & $\begin{array}{c}6 \\
30 \% \\
\end{array}$ & $\begin{array}{c}0.6 \\
70 \% \\
\end{array}$ & $\begin{array}{c}1 \\
120 \% \\
\end{array}$ \\
\hline 6 & $\begin{array}{c}0 \\
0 \% \\
\end{array}$ & $\begin{array}{l}0.6 \\
5 \% \\
\end{array}$ & $\begin{array}{c}1 \\
6 \% \\
\end{array}$ & $\begin{array}{c}0 \\
0 \% \\
\end{array}$ & $\begin{array}{c}0.4 \\
40 \% \\
\end{array}$ & $\begin{array}{c}0.4 \\
20 \% \\
\end{array}$ & $\begin{array}{c}7 \\
40 \% \\
\end{array}$ & $\begin{array}{c}0.6 \\
30 \% \\
\end{array}$ & $\begin{array}{c}60 \\
20 \% \\
\end{array}$ & $\begin{array}{c}3 \\
120 \% \\
\end{array}$ & $\begin{array}{c}1 \\
50 \% \\
\end{array}$ & $\begin{array}{c}550 \\
60 \% \\
\end{array}$ & $\begin{array}{c}1000 \\
110 \% \\
\end{array}$ & $\begin{array}{c}130 \\
40 \% \\
\end{array}$ & $\begin{array}{l}970 \\
60 \% \\
\end{array}$ & $\begin{array}{c}110 \\
20 \% \\
\end{array}$ & $\begin{array}{c}10 \\
70 \% \\
\end{array}$ & $\begin{array}{c}5 \\
30 \% \\
\end{array}$ & $\begin{array}{c}2 \\
260 \% \\
\end{array}$ & $\begin{array}{c}3 \\
250 \% \\
\end{array}$ \\
\hline 7 & $\begin{array}{c}10 \\
0.6 \% \\
\end{array}$ & $\begin{array}{c}0 \\
0 \% \\
\end{array}$ & $\begin{array}{c}2 \\
10 \% \\
\end{array}$ & $\begin{array}{c}4 \\
4 \% \\
\end{array}$ & $\begin{array}{c}0.7 \\
70 \% \\
\end{array}$ & $\begin{array}{c}0.9 \\
50 \% \\
\end{array}$ & $\begin{array}{c}4 \\
20 \% \\
\end{array}$ & $\begin{array}{c}0.6 \\
30 \% \\
\end{array}$ & $\begin{array}{c}90 \\
20 \% \\
\end{array}$ & $\begin{array}{c}1 \\
60 \% \\
\end{array}$ & $\begin{array}{c}3 \\
100 \% \\
\end{array}$ & $\begin{array}{r}630 \\
80 \% \\
\end{array}$ & $\begin{array}{c}950 \\
110 \% \\
\end{array}$ & $\begin{array}{r}250 \\
80 \% \\
\end{array}$ & $\begin{array}{l}1490 \\
90 \% \\
\end{array}$ & $\begin{array}{c}260 \\
50 \% \\
\end{array}$ & $\begin{array}{c}6 \\
40 \% \\
\end{array}$ & $\begin{array}{c}5 \\
20 \% \\
\end{array}$ & $\begin{array}{c}1 \\
110 \% \\
\end{array}$ & $\begin{array}{c}2 \\
130 \% \\
\end{array}$ \\
\hline 8 & $\begin{array}{c}8 \\
0.4 \%\end{array}$ & $\begin{array}{c}0 \\
0 \%\end{array}$ & $\begin{array}{c}1 \\
5 \%\end{array}$ & $\begin{array}{c}4 \\
4 \%\end{array}$ & $\begin{array}{c}0.6 \\
60 \%\end{array}$ & $\begin{array}{c}0.9 \\
50 \%\end{array}$ & $\begin{array}{c}4 \\
20 \%\end{array}$ & $\begin{array}{c}0.7 \\
40 \%\end{array}$ & $\begin{array}{c}240 \\
70 \%\end{array}$ & $\begin{array}{c}1 \\
40 \%\end{array}$ & $\begin{array}{c}2 \\
80 \%\end{array}$ & $\begin{array}{c}530 \\
60 \%\end{array}$ & $\begin{array}{c}980 \\
110 \%\end{array}$ & $\begin{array}{c}250 \\
80 \%\end{array}$ & $\begin{array}{c}1660 \\
100 \%\end{array}$ & $\begin{array}{c}190 \\
40 \%\end{array}$ & $\begin{array}{c}10 \\
50 \%\end{array}$ & $\begin{array}{c}6 \\
30 \%\end{array}$ & $\begin{array}{c}2 \\
200 \%\end{array}$ & $\begin{array}{c}3 \\
220 \%\end{array}$ \\
\hline 9 & $\begin{array}{c}8 \\
0.4 \% \\
\end{array}$ & $\begin{array}{c}0 \\
0 \% \\
\end{array}$ & $\begin{array}{c}2 \\
7 \% \\
\end{array}$ & $\begin{array}{c}6 \\
6 \% \\
\end{array}$ & $\begin{array}{c}0.8 \\
80 \% \\
\end{array}$ & $\begin{array}{c}1 \\
60 \% \\
\end{array}$ & $\begin{array}{c}3 \\
20 \% \\
\end{array}$ & $\begin{array}{c}0.7 \\
40 \% \\
\end{array}$ & $\begin{array}{c}100 \\
30 \% \\
\end{array}$ & $\begin{array}{c}2 \\
80 \% \\
\end{array}$ & $\begin{array}{c}3 \\
100 \% \\
\end{array}$ & $\begin{array}{c}880 \\
110 \% \\
\end{array}$ & $\begin{array}{c}1070 \\
120 \% \\
\end{array}$ & $\begin{array}{c}250 \\
80 \% \\
\end{array}$ & $\begin{array}{c}1570 \\
100 \% \\
\end{array}$ & $\begin{array}{c}370 \\
70 \% \\
\end{array}$ & $\begin{array}{c}3 \\
20 \% \\
\end{array}$ & $\begin{array}{c}6 \\
30 \% \\
\end{array}$ & $\begin{array}{c}0.4 \\
50 \% \\
\end{array}$ & $\begin{array}{c}0.9 \\
70 \% \\
\end{array}$ \\
\hline $\begin{array}{c}10 \\
\mathrm{Ctrl}^{\mathrm{e}}\end{array}$ & $\begin{array}{c}7 \\
0.4 \% \\
\end{array}$ & $\begin{array}{c}0 \\
0 \% \\
\end{array}$ & $\begin{array}{c}2 \\
8 \% \\
\end{array}$ & $\begin{array}{c}6 \\
6 \% \\
\end{array}$ & $\begin{array}{c}0.8 \\
80 \% \\
\end{array}$ & $\begin{array}{c}1 \\
60 \% \\
\end{array}$ & $\begin{array}{c}3 \\
20 \% \\
\end{array}$ & $\begin{array}{c}0.7 \\
40 \% \\
\end{array}$ & $\begin{array}{c}70 \\
20 \% \\
\end{array}$ & $\begin{array}{c}2 \\
90 \% \\
\end{array}$ & $\begin{array}{c}3 \\
110 \% \\
\end{array}$ & $\begin{array}{c}910 \\
110 \% \\
\end{array}$ & $\begin{array}{c}1070 \\
120 \% \\
\end{array}$ & $\begin{array}{l}250 \\
80 \% \\
\end{array}$ & $\begin{array}{c}1560 \\
100 \% \\
\end{array}$ & $\begin{array}{c}390 \\
70 \% \\
\end{array}$ & $\begin{array}{c}3 \\
10 \% \\
\end{array}$ & $\begin{array}{c}6 \\
30 \% \\
\end{array}$ & $\begin{array}{c}0.4 \\
40 \% \\
\end{array}$ & $\begin{array}{c}0.6 \\
50 \% \\
\end{array}$ \\
\hline
\end{tabular}

a. Micronutrient levels obtained by using the International Minilist procedure are reasonable approximations. These values have been estimated by using as the principal reference the International Minilist (IML) together with certain more applicable values from other databases [15, 23, 24]. Suitable nutrient corrections have been made for commodity processing [25]. Thia = thiamin; Ribf = riboflavin; Nia = niacin; Fol = folate; Pant = pantothenic acid

b. The recommended nutrient intakes (RNIs) used for comparison are those proposed by M.H. Golden for special complementary or supplementary foods which are formulated to treat moderately malnourished children [6]. It is assumed that further complementation is achieved with breast milk, local market and home-produced foods, and specific micronutrient powders or fortified fat-based spreads

c. Rounding is used because the IML approach is an estimation. The rounding procedure results in approximate but not exact correspondence between micronutrient levels and RNI values

d. Both the estimated levels and the corresponding percent RNI values have been rounded off: numbers from 0 to 10 to one decimal place numbers from 1 to 10 to the nearest integer, and numbers $>10$ to the nearest 10 percent

e. $C t r l=$ control blend 


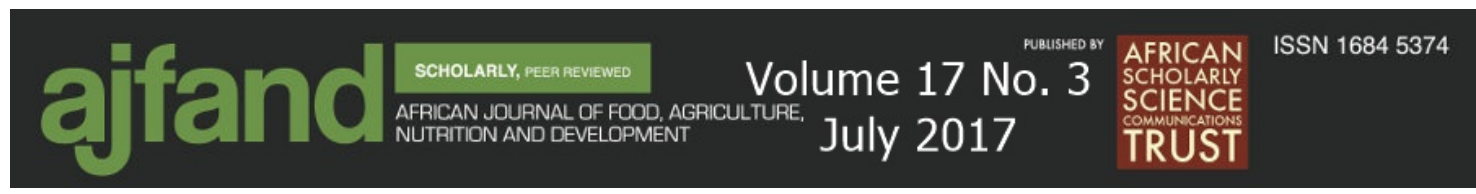

\section{Table 4: Cooked porridge appearance, flavor, mouthfeel (texture) and child suitability; statistical comparisons of mothers' judgements}

\begin{tabular}{|c|c|c|c|c|c|c|c|c|c|c|c|}
\hline \multicolumn{12}{|c|}{$\begin{array}{c}\text { Mothers' five-point hedonic scale difference rating }{ }^{\mathrm{a}} \\
\text { Adjusted means (S.E. })^{\mathrm{b}}\end{array}$} \\
\hline Porridge No. & 1 & 2 & \begin{tabular}{l|l}
3 & \\
\end{tabular} & 4 & \multicolumn{2}{|c|}{5} & \multicolumn{2}{|c|}{6} & 7 & \multirow{2}{*}{\begin{tabular}{c|c|}
8 \\
-0.67
\end{tabular}} & \multirow{3}{*}{$\begin{array}{c}9 \\
-0.36 \\
(0.29)\end{array}$} \\
\hline \multirow[t]{2}{*}{ Appearance (A) } & -0.47 & -0.55 & -0.44 & -0.19 & & 23 & -2 & & -1.02 & & \\
\hline & $(0.28)$ & $(0.28)$ & $(0.29)$ & $(0.29)$ & & 29) & $(0$. & & $(0.30)$ & $(0.30)$ & \\
\hline \multirow[t]{2}{*}{$\underline{\text { Flavor }(\mathrm{F})}$} & -0.43 & -0.68 & -0.19 & -0.18 & \multirow{2}{*}{\multicolumn{2}{|c|}{$\begin{array}{c}0.03 \\
(0.34)\end{array}$}} & \multirow{2}{*}{\multicolumn{2}{|c|}{$\begin{array}{l}-2.08 \\
(0.34)\end{array}$}} & \multirow{2}{*}{$\begin{array}{l}-1.11 \\
(0.35)\end{array}$} & -1.00 & -0.33 \\
\hline & $(0.33)$ & $(0.33)$ & $(0.34)$ & $(0.34)$ & & & & & & $(0.34)$ & $(0.33)$ \\
\hline \multirow[t]{2}{*}{ Mouthfeel (MF) } & -0.37 & -0.67 & $-0.31)$ & -0.60 & \multirow{2}{*}{\multicolumn{2}{|c|}{$\begin{array}{c}0.10 \\
(0.33)\end{array}$}} & \multirow{2}{*}{\multicolumn{2}{|c|}{$\begin{array}{l}-2.14 \\
(0.33)\end{array}$}} & \multirow{2}{*}{$\begin{array}{l}-1.51 \\
(0.34)\end{array}$} & -1.03 & -0.18 \\
\hline & $(0.33)$ & $(0.32)$ & $(0.33)$ & $(0.33)$ & & & & & & $(0.34)$ & $(0.33)$ \\
\hline \multirow[t]{2}{*}{ Child Suitability (CS) } & -0.14 & -0.58 & -0.28 & -0.27 & \multirow{2}{*}{\multicolumn{2}{|c|}{$\begin{array}{l}-0.02 \\
(0.41)\end{array}$}} & \multirow{2}{*}{\multicolumn{2}{|c|}{$\begin{array}{l}-1.88 \\
(0.41)\end{array}$}} & \multirow{2}{*}{$\begin{array}{l}-1.15 \\
(0.42)\end{array}$} & -0.82 & -0.44 \\
\hline & $(0.40)$ & $(0.40)$ & $(0.41)$ & $(0.41)$ & & & & & & $(0.41)$ & $(0.41)$ \\
\hline \multicolumn{12}{|c|}{ Probability of statistical significance for paired mean comparisons A, F, MF, $\mathrm{CS}^{\mathrm{c}}$} \\
\hline Porridge No. & 1 & 2 & 33 & & & & 5 & & 6 & 7 & 8 \\
\hline 2 & n.s $\mathrm{s}^{\mathrm{d}}$ & & & & & & & & & & \\
\hline 3 & n.s & n.s & & & & & & & & & \\
\hline 4 & n.s & n.s. & n.s. & & & & & & & & \\
\hline 5 & n.s. & $\begin{array}{l}\text { A: n.s. } \\
\text { F: * } \\
\text { MF: n.s. } \\
\text { CS: n.s. }\end{array}$ & n.s. & n.s. & & & & & & & \\
\hline 6 & $\begin{array}{l}\mathrm{A}: * * * \\
\mathrm{~F}: * * * \\
\mathrm{MF}: * * * \\
\mathrm{CS}: * * *\end{array}$ & $\begin{array}{l}\mathrm{A}: * * * \\
\mathrm{~F}: * * * \\
\mathrm{MF}: * * * \\
\mathrm{CS}: * *\end{array}$ & $\begin{array}{l}\text { A: } * * * \\
\text { F: } * * * \\
\text { MF: } * * * \\
\text { CS: } * * *\end{array}$ & $\begin{array}{l}\text { A: } \\
\text { F: } \\
\text { MF } \\
\text { CS: }\end{array}$ & & & $\begin{array}{l}* * \\
* * \\
* * * \\
* * *\end{array}$ & & & & \\
\hline 7 & $\begin{array}{l}\text { A: n.s. } \\
\text { F: n.s. } \\
\text { MF: ** } \\
\text { CS: * }\end{array}$ & $\begin{array}{l}\text { A: n.s. } \\
\text { F: n.s. } \\
\text { MF: * } \\
\text { CS: n.s. }\end{array}$ & $\begin{array}{l}\text { A: n.s. } \\
\text { F: ** } \\
\text { MF: ** } \\
\text { CS: n.s. }\end{array}$ & $\begin{array}{l}\text { A: } \\
\text { F: } \\
\text { MF } \\
\text { CS: }\end{array}$ & & $\begin{array}{l}\text { A: } \\
\text { F: } \\
\text { MF } \\
\text { CS }\end{array}$ & $\begin{array}{l}* \\
* * \\
* * * \\
* * \\
\end{array}$ & & $\begin{array}{l}* * \\
* * \\
\text { n.s. } \\
\text { n.s. }\end{array}$ & & \\
\hline 8 & n.s. & n.s. & $\begin{array}{l}\text { A: n.s. } \\
\text { F: * } \\
\text { MF: n.s. } \\
\text { CS: n.s. }\end{array}$ & $\begin{array}{l}\text { A: } \\
\text { F: } \\
\text { MF } \\
\text { CS: }\end{array}$ & & $\begin{array}{l}\text { A: } \\
\text { F: } \\
\text { MF } \\
\text { CS }\end{array}$ & & & $\begin{array}{l}* * * \\
* * \\
* * \\
* *\end{array}$ & n.s. & \\
\hline 9 & n.s. & n.s. & n.s. & n.s. & & n.s & & & $\begin{array}{l}* * * \\
* * \\
* * * \\
* * *\end{array}$ & $\begin{array}{l}\text { A: * } \\
\text { F: * } \\
\text { MF: *** } \\
\text { CS: n.s. }\end{array}$ & $\begin{array}{l}\text { A: n.s. } \\
\text { F: n.s. } \\
\text { MF: * } \\
\text { CS: n.s. }\end{array}$ \\
\hline
\end{tabular}

a. The hedonic scale difference rating for a given feature is the hedonic scale score assigned to a given porridge (no. 1 through 9) minus the score assigned by that mother to the designated control porridge (no. 10). A positive difference signifies a higher score and a negative difference signifies a lower score than the control. The average score for the control porridge is 4.24 (appearance), 4.34 (flavor), 4.41 (mouthfeel), 4.30 (child suitability)

b. Mean and standard error of means are based on the average of 9 to 13 mothers per session and then averaged over 4 sessions

c. T-tests were used for pairwise comparisons based on error measurements from analysis of variance (ANOVA) of hedonic scale difference ratings. Significance is indicated with * for $p \leq$ $0.1, * *$ for $p \leq 0.05$ and $* * *$ for $p \leq 0.01$.

d. n.s. indicates no significant differences found $(p>0.1)$ 


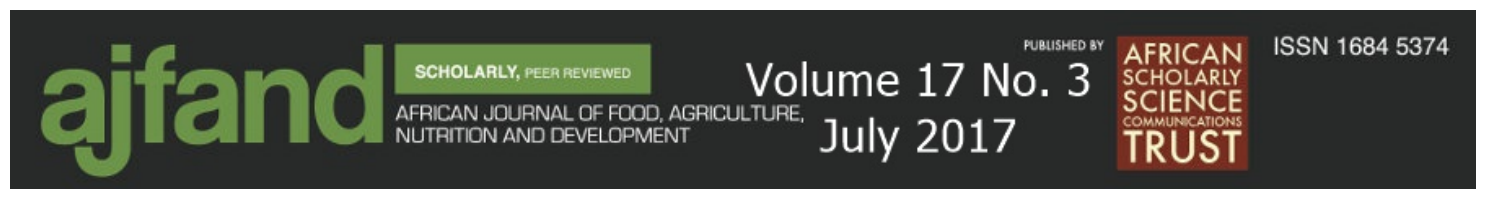

Table 5: Ingredient set suitability with respect to ingredient composition and
utilization elements: statistical comparison of mothers' judgments

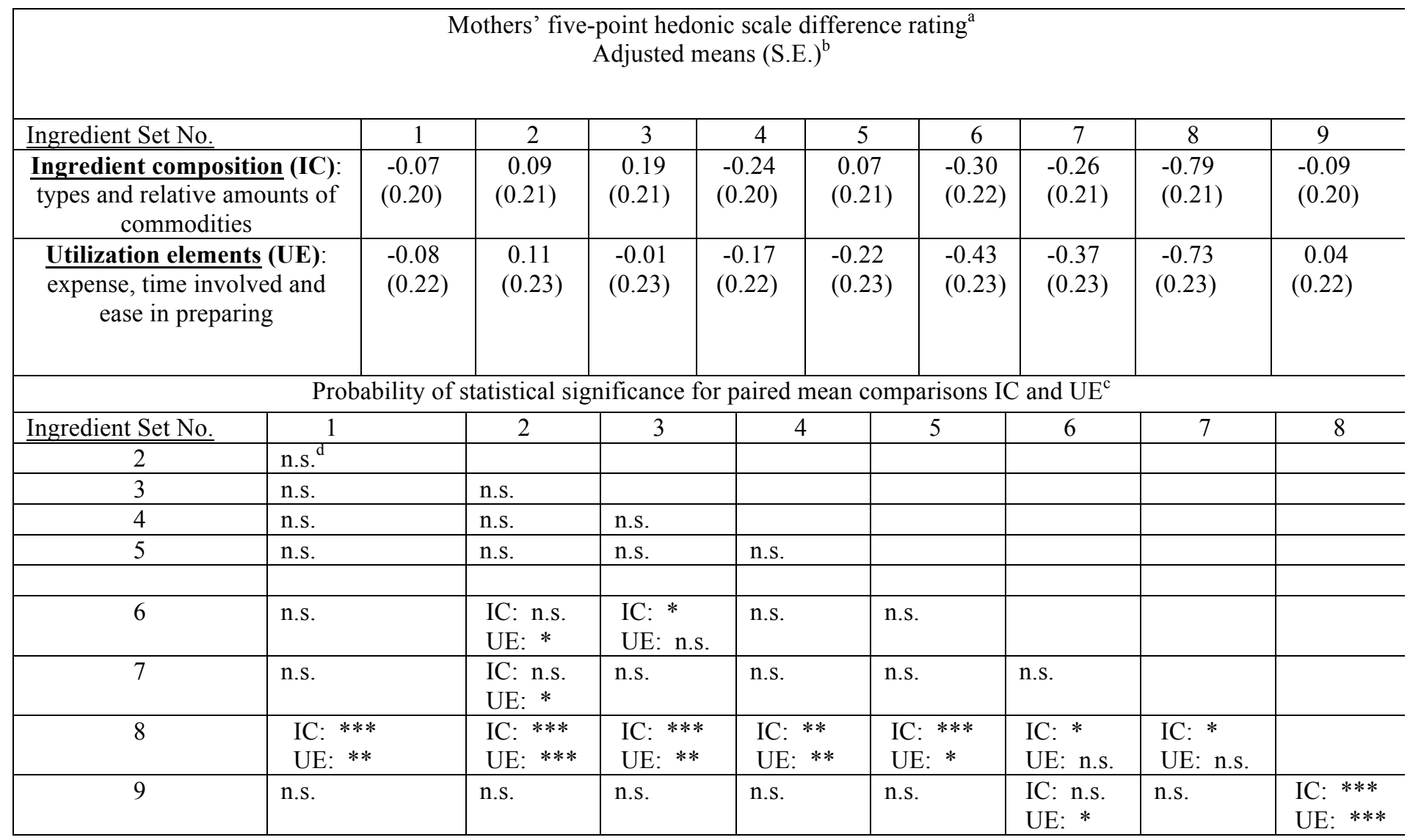

a. The hedonic scale difference rating for a given feature is the hedonic scale score assigned to a given ingredient set (no. 1 through 9) minus the score assigned by that mother to the designated control ingredient set (no.10). A positive difference signifies a higher score, and a negative difference signifies a lower score than the control The average score for the control ingredient set is 4.57 (ingredient composition - IC) and 4.52 (utilization elements - UE)

b. Mean and standard error of means are based on the average of 9 to 15 mothers per session and then averaged over 4 sessions

c. T-tests were used for pairwise mean comparisons based on error measurements from analysis of variance (ANOVA) of hedonic scale difference ratings. Significance is indicated with * for $p$ $\leq 0.1$, ** for $p \leq 0.05$ and $* * *$ for $p \leq 0.01$

d. n.s. indicates no significant differences found $(p>0.1)$ 


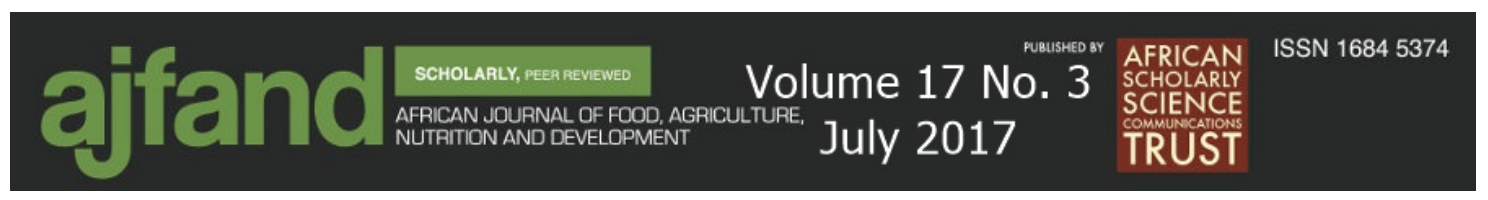

\section{Table 6: Strengths of association among average hedonic scale cooked porridge and ingredient set quality factors difference ratings ${ }^{\mathrm{a}}$ by mothers}

\begin{tabular}{|c|c|c|c|c|c|}
\hline \multicolumn{6}{|c|}{ Pearson correlation coefficient/two-tailed significance level ${ }^{\mathrm{b}}$} \\
\hline$\frac{\underline{\text { Blend }}}{\text { quality }}$ & $\begin{array}{l}\text { Porridge: } \\
\underline{\text { cooked }} \\
\text { appearance }\end{array}$ & $\frac{\text { Porridge: }}{\underline{\text { cooked }}}$ & $\begin{array}{l}\frac{\text { Porridge: }}{\text { cooked }} \\
\text { mouthfeel } \\
\end{array}$ & $\frac{\frac{\text { Porridge: }}{\text { cooked }}}{\underline{\text { child }}}$ & $\begin{array}{l}\frac{\frac{\text { Ingredient }}{\text { Composition: }}}{\frac{\text { types and }}{\text { relative amounts }}} \\
\frac{\text { of uncooked }}{\text { commodities }}\end{array}$ \\
\hline $\begin{array}{l}\text { Porridge: } \\
\text { cooked flavor }\end{array}$ & $0.91 / * * *$ & & & & \\
\hline $\begin{array}{l}\text { Porridge: } \\
\text { cooked } \\
\text { mouthfeel }\end{array}$ & $0.91 / * * *$ & $0.93 / * * *$ & & & \\
\hline $\begin{array}{c}\text { Porridge: } \\
\text { cooked } \\
\text { child suitability }\end{array}$ & $0.87 / * * *$ & $0.94 / * * *$ & $0.93 / * * *$ & & \\
\hline $\begin{array}{l}\text { Ingredient Composition: } \\
\text { types and relative amounts } \\
\text { of uncooked commodities }\end{array}$ & $0.13 /$ n.s. $^{\mathrm{c}}$ & $0.32 /$ n.s. & $0.33 /$ n.s. & $0.11 /$ n.s. & \\
\hline $\begin{array}{l}\text { Utilization Elements: } \\
\text { expense, time involved and } \\
\text { ease in preparation }\end{array}$ & $0.03 / \mathrm{n} . \mathrm{s}$ & $0.21 /$ n.s. & $0.18 /$ n.s. & $0.00 /$ n.s. & $0.92 / * * *$ \\
\hline
\end{tabular}

a. For each mother evaluator, the hedonic scale difference rating for a given feature is the hedonic scale score assigned to a given porridge (no. 1 through 9) or ingredient set (no. 1 through 9) minus the score assigned by that mother to the control porridge (no. 10) or to the control ingredient set (no. 10). A positive difference signifies a higher score, and a negative difference signifies a lower score than the control. The sets of uncooked ingredients for each of the ten mixtures were evaluated by the mothers both with respect to the types of and relative amounts of composite commodities and also with respect to estimated expense together with time involved and ease of preparation into porridge

b. $\quad * * *=p \# 0.01$; the table values represent averages over blends no. 1 through 9 of mothers, transformed hedonic score ratings for the respective factors listed in the table

c. $\quad$ n.s. indicates no significant difference found $(p>0.1)$ 


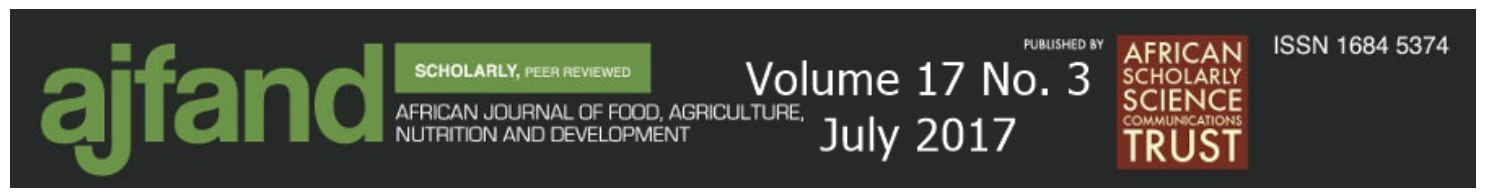

Table 7: Comparative suitability of evaluated weaning blends (listed in descending order of estimated merit)

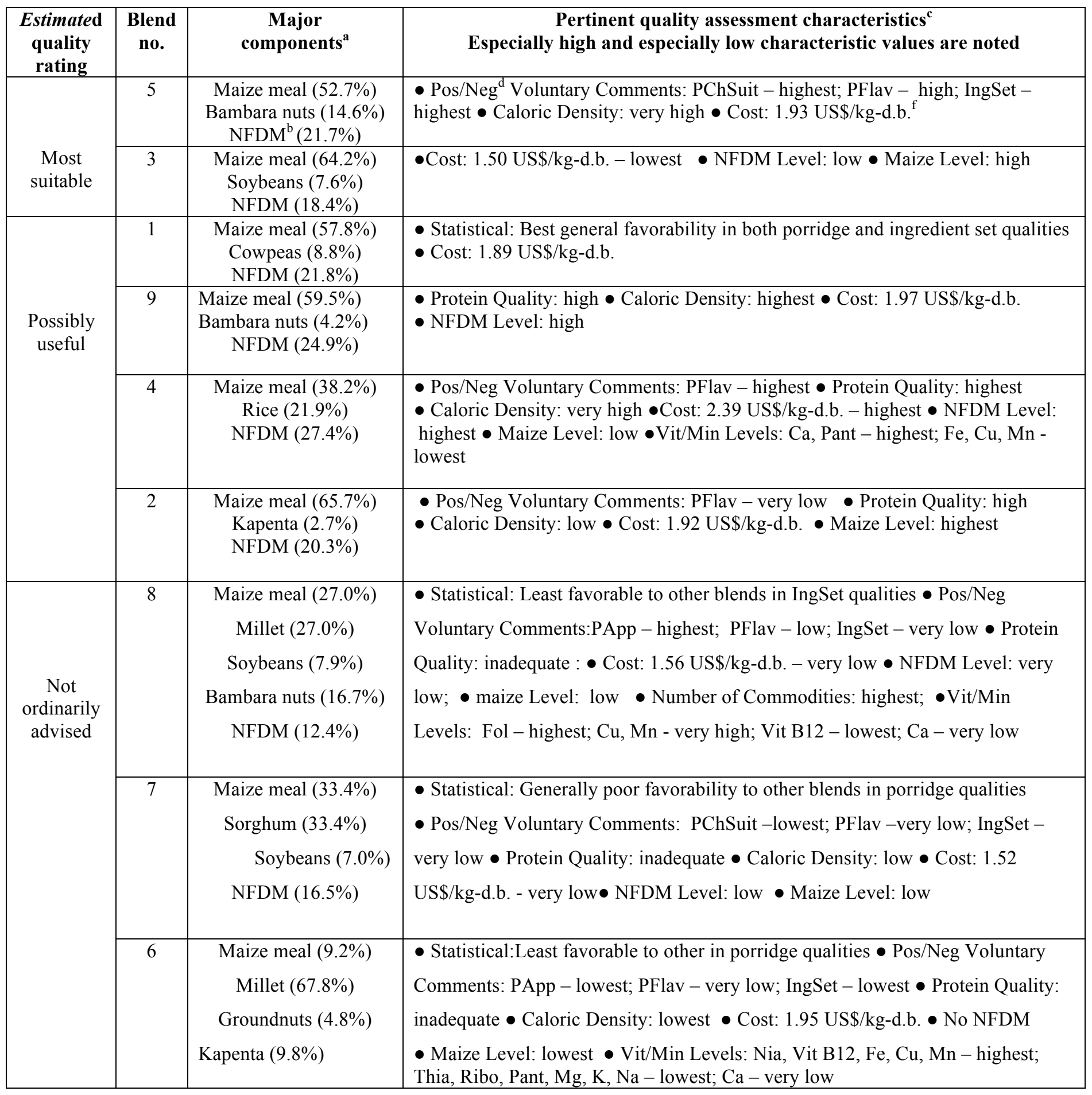

a. Percent "as is -including normal moisture" of blend components exclusive of sugar and oil. The major components of the control blend number 10 are maize meal (62.2\%) and NFDM (26.1\%). That blend cost is 1.96 US\$/kg - d.b Complete blend compositions are reported in 


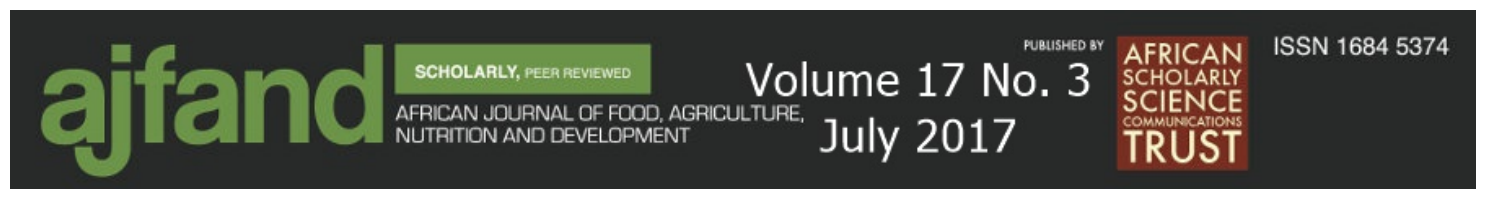

Table 1 together with brief processing descriptions. More detailed reference to processing steps is found in the text

b. Nonfat dry milk

c. These listings represent a summary of salient results from Tables 1 through 5 and blend costs, together with results of mothers'voluntary comments concerning uncooked ingredients and cooked porridges as noted in the text. The factors chosen were considered the most relevant in establishing the order of merit for the blends

d. This represents the ratio of positive (or favorable) comments to negative (or unfavorable) comments volunteered by the mother on a given quality feature. PApp = porridge appearance; PChSuit $=$ porridge child suitability; PFlav $=$ porridge flavor $;$ IngSet $=$ ingredient set factors

e. The descriptive designations for caloric density relate to its proximity to that of breast milk or higher, at the start of weaning

f. $\quad$ d.b. $=$ dry basis

g. With respect to those vitamins and minerals specifically noted in Table 7: Thia, Ribo, Nia, B12, and Pant refer to thiamin, riboflavin, niacin, vitamin $B$ 12, and pantothenic acid respectively. $\mathrm{Ca}, \mathrm{Mg}, \mathrm{K}, \mathrm{Na}, \mathrm{Fe}, \mathrm{Zn}, \mathrm{Cu}$ and $\mathrm{Mn}$ refer to calcium, magnesium, potassium, sodium, iron, zinc, copper and manganese respectively. Not cited in Table 7 are the fat-soluble vitamins, which are low in all the blends 


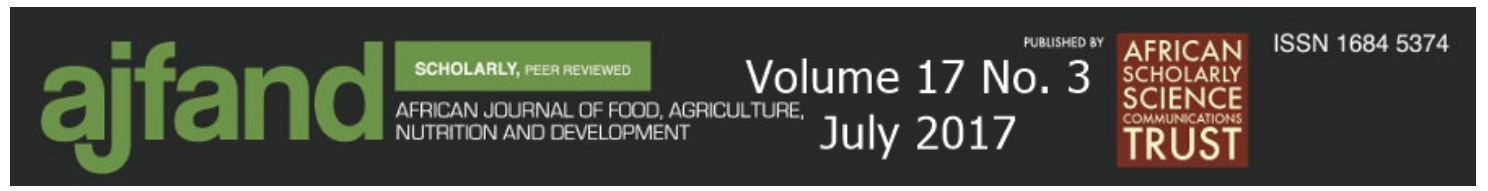

\section{REFERENCES}

1. Souganidis E The relevance of micronutrients to the prevention of stunting. Sight Life Mag. 2012; 26(2): 10-18.

2. Central Statistics Office (CSO). Ministry of Health, Tropical Diseases Research Centre, University Teaching Hospital - Virology Laboratory, University of Zambia, The DHS Program - ICF International. Zambia Demographic and Health Survey 2013-2014. Preliminary Report. The DHS Program - ICF International, Rockville, MD, USA; Sept. 2014.

3. Thurnham DI Adequate nutrient intakes for infancy. Part 3: Adequate nutrition for children 24 to 59 months. Sight Life Mag. 2013; 27(2): 32-43.

4. Kraemer K The stunting enigma (commentary). Sight Life Mag. 2013; 27(2): 12-15.

5. Bloem M Preventing stunting: why it matters, what it takes. In: Eggersdorfer M, Ruel M, Biesalski HK, Chen J, Mannar V, Kraemer K,Van Ameringen M, Bloem $\mathbf{M}$ and $\mathbf{A}$ Lateef (Eds) The road to good nutrition - a global perspective. Basel, Switzerland: S. Karger AG, 2013; 1: 13-23.

6. Golden MH Proposed recommended nutrient densities for moderately malnourished children. Food Nutr Bull. 2009; 30(3) (Suppl): S267-S342.

7. Michaelsen KF, Hoppe C, Roos N, Kaestel P, Stougaard M, LauritzenL, Molgaard $\mathbf{C}$, Girma $\mathbf{T}$ and $\mathbf{H}$ Friis Choice of foods and ingredients for moderately malnourished children 6 months to 5 years of age. Food Nutr Bull. 2009; 30(3) (Suppl): S343-S403.

8. Hayes RE, Mwale JM, Tembo $\mathbf{P}$ and JI Wadsworth Computer-optimized weaning food blends. Food Nutr Bull. 1995; 16(3): 245-262.

9. Hayes RE, Mwale JM, Bwembya PA, Mulenga MK and AB Vermoer Weaning practices and foods in high population-density areas of Lusaka, Zambia. Ecol Food Nut. 1994; 33: 45-74.

10. Pellett PL and VR Young (Eds) Nutritional evaluation of protein foods. Joint United Nations University and International Union of Nutritional Sciences Working Group. United Nations University Press, Toyko, 1980.

11. Pelto GH, Levitt $\mathbf{E}$ and $\mathbf{L}$ Thairu Improving feeding practices: current patterns, common constraints, and the design of interventions. Food Nutr Bull. 2003; 24(1): 45-82.

12. FAO/WHO. Codex Alimentarius: Guidelines on formulated supplementary foods for older infants and young children. Report No.: CAC/GL 08-1991.Food and Agriculture Organization of the United Nations, Rome, 1991. 


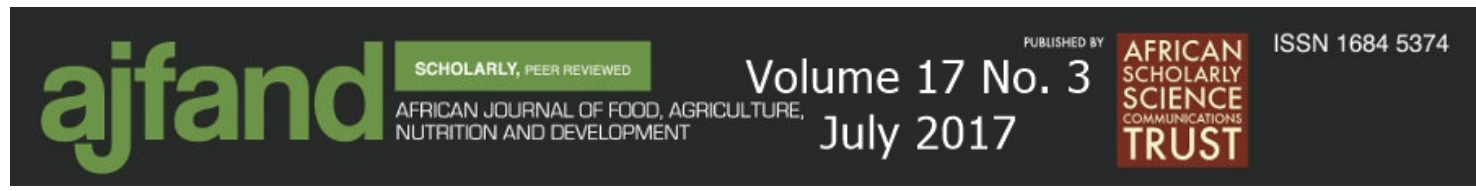

13. Joint FAO/WHO/UNU Expert Consultation. Energy and protein requirements. WHO Technical Report Series 724. World Health Organization, Geneva, 1985.

14. Joint WHO/FAO/UNU Expert Consultation. Protein and amino acid requirements in human nutrition. WHO Technical Report Series 935. World Health Organization, Geneva, 2007.

15. FAO. World Food Dietary Assessment System, Version 2. Infoods. Food and Agriculture Organization of the United Nations, Rome, 2003. May be downloaded from http://fao.org/infoods. Accessed 7 June 2014.

16. Parsonage $\mathbf{S}$ and $\mathbf{J}$ Clark Infant nutrition and family nutrition. $\mathrm{HM}+\mathrm{M}$ Publishers Ltd, London, 1981:1.

17. Stone H, Bleibaum $\mathbf{R}$ and HA Thomas Sensory evaluation practices, $4^{\text {th }}$ Ed. Academic Press, Waltham, MA, USA, 2012: 126-127.

18. Guptill KS, Esrey SA, Oni GA and KH Brown Evaluation of a face-to face weaning food intervention in Kwara State, Nigeria: knowledge, trial, and adoption of a home-prepared weaning food. Soc Sci Med. 1993; 36(5): 665672.

19. Dewey KG, Cohen RJ and NC Rollins WHO technical background paper: feeding of non-breastfed children from 6 to 24 months of age in developing countries. Food Nutr Bull. 2004; 25(4): 377-402.

20. Thea DM, Vwalika C, Kasonde P, Kankasa C, Sinkala M, Semrau K, Shutes E, Ayash C, Tsai W, Aldrovandi G and L Kuhn Issues in the design of a clinical trial with a behavioral intervention - the Zambia exclusive breastfeeding study. Control Clin Trials. 2004; 25(4): 353-365.adoption of a home-prepared weaning food. SocSci Med. 1993; 36(5): 665-672.

21. Holz C, Lubowa A, Sison C, Moursi M and C Loechl A food composition table for Central and Eastern Uganda. HarvestPlus Technical Monograph 9. International Food Policy Research Institute and International Center for Tropical Agriculture (CIAT), Washington, DC and Cali, Columbia, 2012.

22. Stadlmayr B, Charrondiere UR, Enujiugha VN, Bayili RG,Fagbohoun EG, Samb B, Addy P, Barikmo I, Ouattara F, Oshaug A, Akinyele I, Annor GA, Bomfeh K, Ene-Obong H, Smith IF, Thiam I and B Burlingame West African food composition table. Food and Agriculture Organization of the United Nations, Rome, 2012.

23. Wolmarans P, Danster N, Dalton A, Rossouw $K$ and $H$ Schönfeldt Condensed food composition table for South Africa. Medical Research Council, Capetown, South Africa, 2010. 


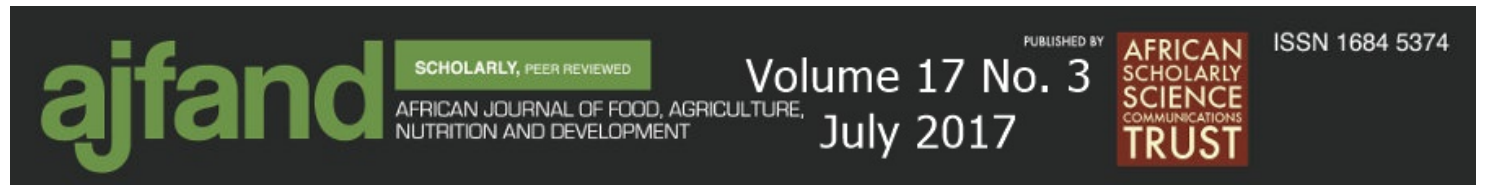

24. Nutrient Data Laboratory. USDA national nutrient database for standard reference, release 25. U.S. Department of Agriculture, Agriculture Research Service, Washington, DC, 2012.

25. Nutrient Data Laboratory. USDA table of nutrient retention factors, release 6 . U.S. Department of Agriculture, Agriculture Research Service, Beltsville, MD, USA, 2007. 